\title{
Gaging the Neural Path of the Universal Grammar by the Logos Heuristics
}

\author{
Antonio Cassella ${ }^{1}$ \\ ${ }^{1}$ President of Research Autism LLC (FL) and Director of Imerisya (Instituto merideño de investigación de la \\ inteligencia social y del autismo, Mérida, Venezuela). \\ Correspondence: Antonio Cassella, 1270 N. Wickham Rd. 16-613, Melbourne, FL, 32935, USA.
}

Received: August 23, 2019

Accepted: September 27, 2019

Available online: October 17, 2019

doi:10.11114/ijsss.v7i6.4567

URL: https://doi.org/10.11114/ijsss.v7i6.4567

\begin{abstract}
The logos heuristics (" $\Lambda$ ”) derived from the fix of autistics - e.g., the strain to tap infinity-can help us gage the Universal Grammar that Charles Sanders Peirce implied in his "Semeiotics" since 1868. Knowledge of that Grammar equates the return of "Quetzal-coatl" in Mesoamerican legends. If that "bird-serpent/sky-land" returned with the Common Sense in Peirce's "Pragmaticism," social science would befit the $3^{\text {rd }}$ Attention behind Dharma. In Dharma, the $2^{\text {nd }}$ restores the $1^{\text {st }}$ attention: infinity, finiteness; quantum, classical computing; doubt, certainty; hyperspace, spacetime; flail, crook; yin, yang; mother, father; water, stones; moon, sun; urim, thummim; nagual, tonal; Shiva, Vishnu; novelty, sameness; mindfullness, focused attention; learning, memory; fantasy, reality; unknown, known; simultaneity, sequence; lying, candor; patience, anger; fluidity, bluntness; less-than-perfection, perfection; witch, muggle; imaginary, real numbers; wine, bread; jury, law; flexibility, rigidity; hope, faith; arch, column; bow, arrow; quantum physics, gravity; and pragmatics in cerebellar microcomplexes, grammar in the neocortex. If the return of Common Sense distanced us from the desire to overwin and replace other species, our young will regain the Earth that hosted saber-toothed cats.
\end{abstract}

Keywords: autism, Universal Grammar, Charles Sanders Peirce, Quetzalcoatl, Common Sense, Pragmaticism, Dharma

\section{Introduction}

Although science and technology are booming, we have repressed knowledge of Common Sense or Dharma, which invited our Stone-Age ancestors to revere nature and the nature of language. Unless we change now, all human societies will soon die. About 150 years ago, Charles Sanders Peirce (“/p3:rs/” IPA ${ }^{1}$ )—an American philosopher, mathematician, and logician-implied that his "Science of Irony" could help us change our obtuse ways. In an article (Peirce, 1868, p. $287, \S 4)$, he remarked two momentous propositions: "There is no griffin" and "A griffin is a winged quadruped."

A gravity-defying "griffin" is made out of a lion and an eagle. I assume that one column of the neocortex (Hawkins, Ahmad, and Cui, 2017) of Peirce's brain welcomed the representation of the king of land animals - the lion; and another column, the king of sky animals - the eagle. A quadruped on land is not a bird in the sky! A "griffin" ("lion-eagle"/"land-sky"), then, echoes the infinite speed that allows us to stand on land, in the sky, and in rival concepts simultaneously. It also implies the link between two representations, or "meta-representation" (a scary word).

High-functioning autistics meta-represent in the finiteness of the first attention; and not in the infinity of the second attention. Contrariwise, nonautistic Down persons handle infinite speed but cannot meta-represent. By defeating both autism and trisomy 21, a griffin reveals the truth of an odd logic in nonautistic humans: The verb "is" in Peirce's sentence, "A griffin is a winged quadruped," denotes real mental creativity, which makes the first sentence false. And if the reality of mental creativity were negated, a double negation too would make false the sentence "There is no griffin."

Together, Peirce's false first sentence and his true second sentence stress the need and insufficiency of the first attention $^{2}$ impaired in Down syndrome (DS), the wonders of the second attention impaired in ASD (Autism Spectrum Disorder), and an irony in the third attention, or the Dharma tapped by Peirce's "Pragmaticism."

\footnotetext{
1 "Peirce" should be pronounced as the word "purse." The acronym "IPA" reflects the International Phonetic Alphabet.

2 In my printed books, I use: a) underlining to stress finiteness, classical computing, and the first attention/intention (1); b) bold to highlight the infinity of quantum computing and the second attention/intention (2); c) their union (or an irregular initial capital), to stress the sociality of the Third Attention/Intention ( $\underline{\mathbf{3}})$; d) the colors blue, red, and green for the first, the second, and the third attention/intention in any figure; and orange, to mark madness.
} 
I posit that, although Peirce never faced the tragedy of autism, he knew that a Universal Grammar hides behind the best science. On July 20, 1969, Neil Armstrong could have said, "The griffin has landed!" Behind Armstrong's wild walk on the Moon stood the rebellious irony of many actor-scientists. There are limits to the freedom of imagination, though!

At the end of the play in which he took in the infinite speed of Hamlet, an actor has to cease (zero) being-and-nonbeing the Prince of Denmark. If that actor would fall into the lunacy that precedes nothingness, enter his home dressed as Hamlet, and call his love "Ophelia," love would not stop her from sending him straight into the nearest madhouse. His behavior would not be ironic. But the merging of justice and tragedy narrated in Hamlet is.

Although Shakespeare died about four centuries ago, his irony continues enriching his audiences; and so could Peirce's Irony do, if we grasped the Science behind his mysterious "Semeiotics." Peirce's Pragmaticism—or the science of irony -implies that any person capable of remembering in the first attention, fantasizing in the second attention, and returning into a humane finiteness with the Third Attention can renew the world by teaching others how to $\underline{\text { read. }}$.

Peirce implied the scientific, mystic, artistic, and philosophical roots of reading in his 1968 article; and yet powerful enemies prevented him from fitting the life of a university professor, launching him into poverty. Out of his weirdness, Peirce masked the "Distributed Hierarchy" of the Universal Grammar in his Semiotics with made-up names (e.g., "rheme"). I wonder if he unveiled that hierarchy in the writings that his wife Juliette consigned to Harvard University. I do know, however, that separating Peirce's "triadic semiotics" from Ferdinand de Saussure's "dyadic semiology" (Deledalle, 2000, p. 112, § 2) will not lead to reading Peirce's Pragmaticism as the end point of a long story.

Peirce's Semiotics agrees with a diagram left in Gorham's Cave at Gibraltar (top left in figure 1)—around 37000 BCE (Before the Common Era) - and the Wisdom of Osiris/Hatshepsut, Yu the Great, Moses, the Buddha, and Quetzalcoatl.

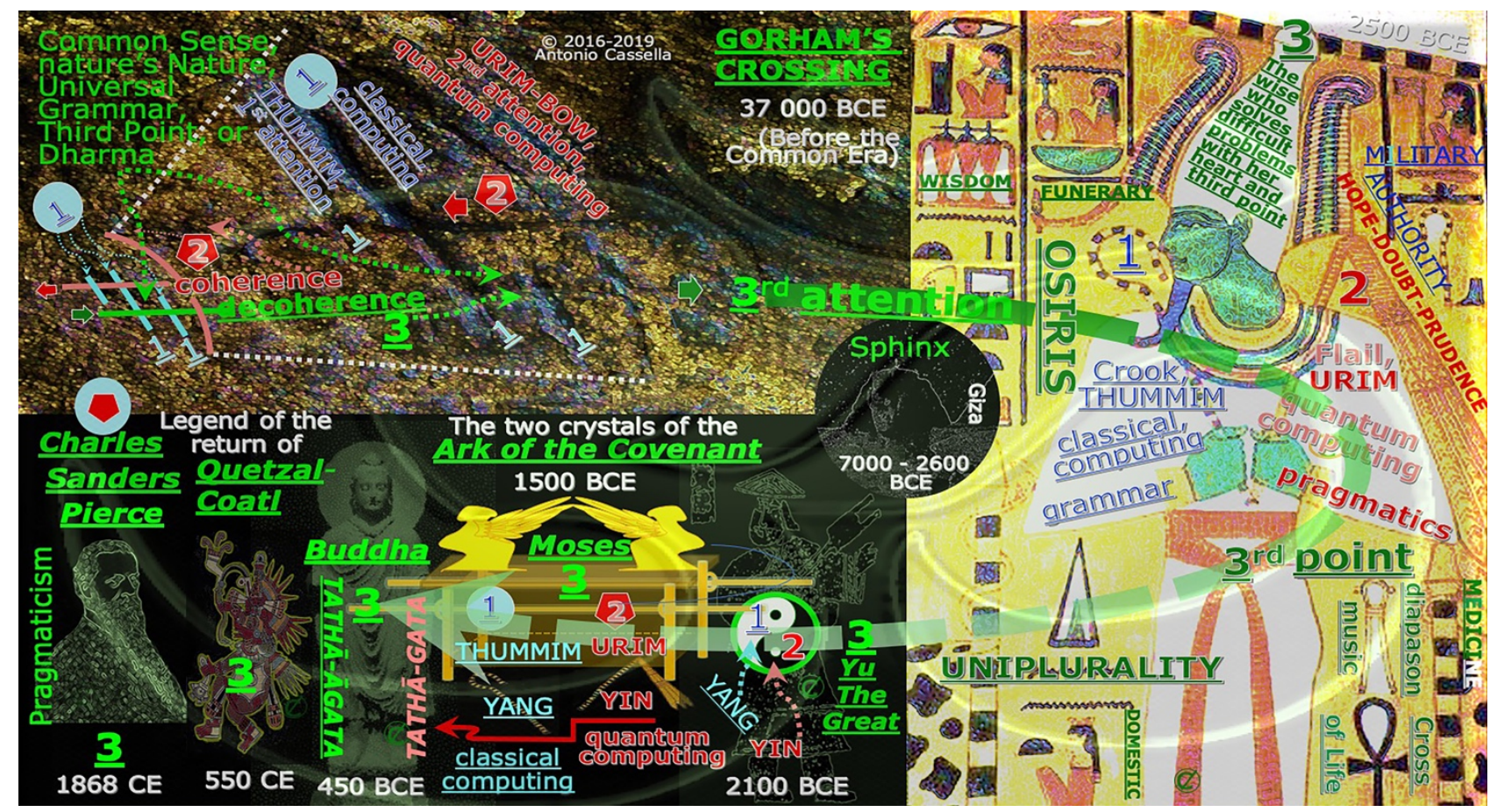

Figure 1. From Gorham’s Cave at Gibraltar to Egypt, China, the Middle East, India, and America

In Gorham's symbolic artwork (Rodríguez-Vidal et al., 2014): Quantum coherence (2) crosses the present and past of Moses" "Thummim," in the classical computing of spacetime (1); and below it, quantum decoherence (3) touches present and future, before crossing a bow (Moses' "Urim") in the quantum computing of hyperspace (2).

Loading a bow makes Moses" "Urim," the going of the Mesoamerican demigod "Coatl-quetzal" ("snake-bird") into infinity within quantum coherence, and tensing the chords of a guitar. And unloading a bow matches decoherence, Andrés Segovia's playing Francisco Tárrega's "Memories of the Alhambra," the return of "Quetzal-coatl" ("Bird-snake") from Venus, and Peirce's science of irony in the Third Point through which Science meets Religion, Art, Philosophy, Music, Language, and nature's Nature. As with the backbreaking geniality of Yu the Great, Moses' heart, and the lovingkindness of the Buddha, the Third Point will help us use infinity in tensing our mental bow to boost Progress, instead of destroying others. 
From Gorham's Cave, the humane union (3) of quantum (2) with classical (1) computing backed the Third Point of:

- The artists that built Giza's epic cat and decorated Bhimbetka's caves (Northern India) around 7000 BCE;

O the Yellow Emperor in 3000 BCE, Osiris in 2500 BCE (Cassella, 2018d), and Yu the Great in 2100 BCE;

- Moses, in the Wisdom received by King Solomon and the Queen of Sheba in the $10^{\text {th }}$ century BCE;

- Laozi/Confucius (China) and the advocates of the Trimurti (India) at the turn of the $6^{\text {th }}$ century BCE;

○ the Buddha/“Tathāgata" ("Thus-gone-and-come"), who spread his loving-kindness in the $5^{\text {th }}$ century BCE;

- Muhammad, when he undertook his "Al-Isrā" and "Wal-Mi'rāi”" travels around 621 CE (Common Era);

- Charles Sanders Peirce about 15 decades ago, when he implied the nature of the Universal Grammar; and

- Gandhi for his "Swarāì" ("self-rule") in a world enriched by wise leaders (e.g., Osiris/Hatshepsut, figure 1).

That union will also back the return of "Quetzal-coatl" ("Bird-serpent") from Venus to Earth through quantum decoherence (at the right of figure 2) with the blessing of "Tonantzin," the "Evening Star," and long-term depression (LTD, in figure 2). ${ }^{4}$

While it may seem useless, illogical, or sinful, "recreation/musement" (2) (Cooke, 2018) precedes Progress ().

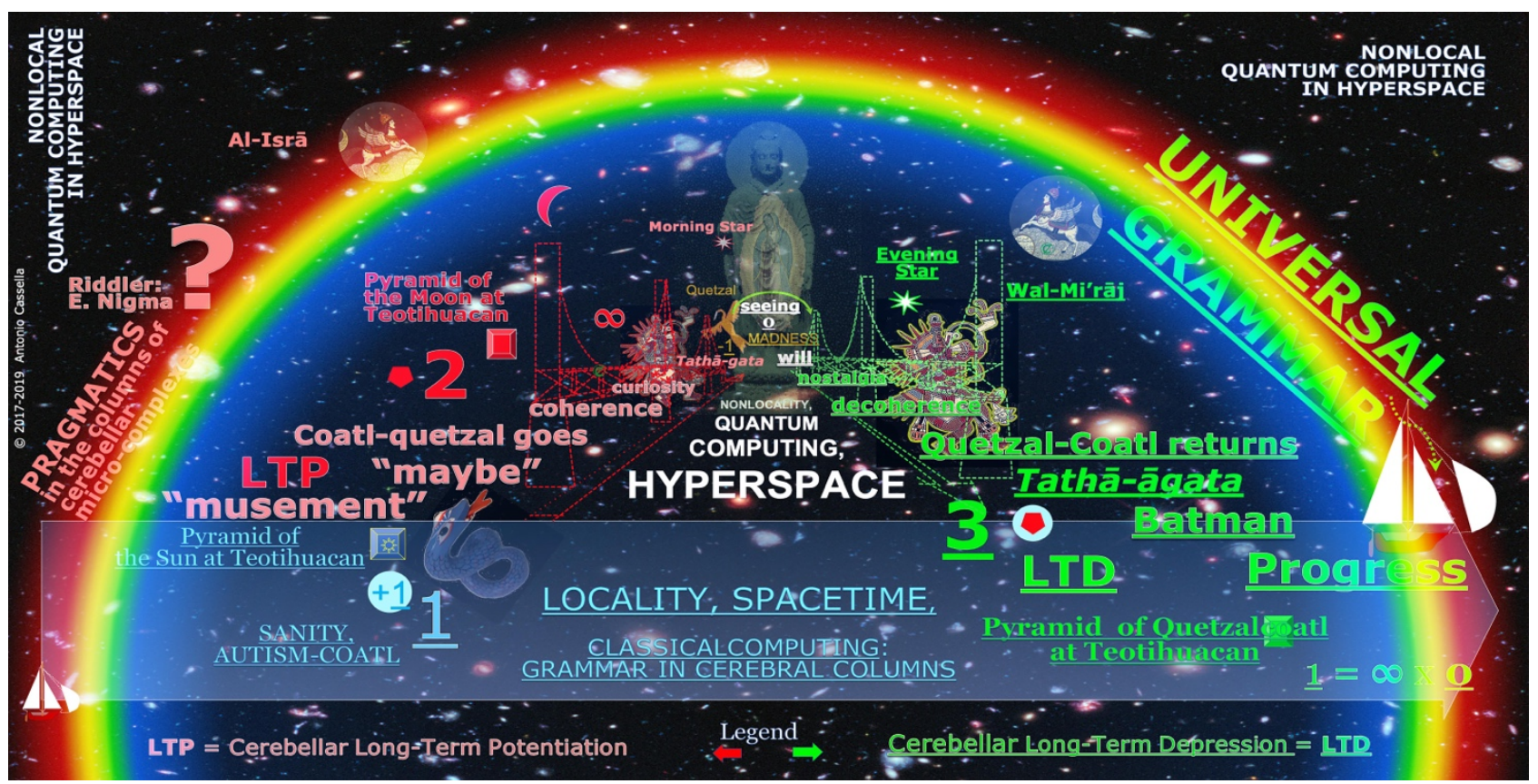

Figure 2. The going of "Coatl-quetzal" (2) and the return of "Quetzal-coatl" (ㅈ) within Progress

Gandhi's "Swarāi" evokes the Third Attention, Progress, the Tathāgata-Buddha, and Quetzalcoatl in two steps: a) going from classical finiteness into quantum infinity with the moon and the morning star (Venus) or LTP (long-term potentiation, left of figure 2), before b) returning to finiteness on Earth with the Evening Star (LTD, at the right).

The social mind of Gandhi, the Buddha, and Quetzalcoatl has guided my scientific exploration of humans' cognitive development (Cassella, 1997, 2000, 2011); global warming (Cassella, 2017a); art (Cassella, 2017b); math (Cassella, 2018a); the bridge between psychology and neuroscience (Cassella 2018b); Sacred Texts (Cassella, 2019a); the link between gravity and quantum physics (Cassella, 2019b); and the Universal Grammar behind Peirce's ironic reading.

Here, I extend Peirce's invitation to read to readers who deny the influence of infinity in finiteness-within the infinite speed unleashed by a griffin or by a piece of information that connects instantaneously two separate pieces of a whole through quantum entanglement and the two slits of a double-slit plate (Feynman, 1985; Icke, 1995; Lloyd, 2006).

\footnotetext{
${ }^{3}$ As with "Kali, Saraswati, Lakshmi, and Parvati" (India), "Tonantzin" reflects the Goddess Mother (among the Aztecs).

4 "Quetzalcoatl" makes the Olmec-Maya-Aztec symbol for gaining the Third Point and the power to control power, which Gandhi deployed by reducing his needs and by enlarging his support to the eventual return of Common Sense.
} 
My search for the Science behind irony and the neural roots of the "universal grammar" aligns with four hypotheses:

a) The union of perfect repetition (the finite Thummim-Tonal-grammar in the $1^{\text {st }}$ attention) with less-than-perfect coherence (the infinite Urim-Nagual-pragmatics in the second attention) heralds decoherence in the Universal Grammar (the Toltec/Mexica Eagle of the Third Attention and Neil Armstrong's ship, "The Eagle");

b) autistics cannot go ( 2 in figure 2) with LTP (cerebellar long-term potentiation) into the less-than-perfect infinity of hyperspace (Caramazza, 1994), toward the lunacy of unreality, with the Nagual/“Coatl-quetzal" ("Snake-bird") and the moon/Morning-Star/second-attention;

c) unmedicated schizophrenics cannot return ( $\underline{\mathbf{3}}$ in figure 2) with $\underline{\text { LTD }}$ (cerebellar long-term depression) from the zero near unreality to the finiteness of shared reality through the Evening-Star/third-attention; and

d) scientific knowledge of the relationship between LTP and LTD (e.g., in using correctly personal pronouns) will help us regain our Third Point and Common Sense, turning the inertia of total defeat into viable Progress.

My journey through the sanity of autistics and the insanity of schizophrenics has deepened the implications of the paradoxical principles of quantum computing (Cassella, 2018c, 2018d, 2018e, 2019a). I compared finite speed in general relativity with infinite speed in quantum physics (Cassella, 2019b) because the finite world in which being opposes nonbeing and the infinite world in which being embraces nonbeing can be complementary within Progress.

I described in that article (Cassella, 2019b) the "logos heuristics" (" $\Lambda$ "), by which . .

- the quantum-computing principles of ubiquity, "An object can exist in separate places simultaneously" (akin to the infinite speed of quantum entanglement [Feynman, 1985]) and coincidence, "Separate objects can share the same space at the same time" (analogous to quantum superposition [Icke, 1995]) readjust ...

- . . the classical-computing principles of locality, "An object cannot exist in separate places simultaneously" (related to Einstein's relativity of simultaneity) and impenetrability, "Separate objects cannot share the same space at the same time" (similar to Pauli Exclusion).

The four principles hide behind my father's figurative explanation about why moving in unison allowed him and his comrades-at-arms to return home safe after World War II: "My platoon survived because we were a shoal of sardines."

He said that the 18 members of his platoon stood simultaneously on land and in the sea (the principle of Ubiquity, or infinity); also, that 18 soldiers and 18 sardines shared the same space at the same time (the principle of Coincidence, zero, or nothingness).

However, I realized that humans and fish live in separate worlds (the principle of Locality) and that 18 sardines never entered the bodies of 18 soldiers (the principle of Impenetrability). The invisibility of metaphorical hyperspace $(\infty$, or

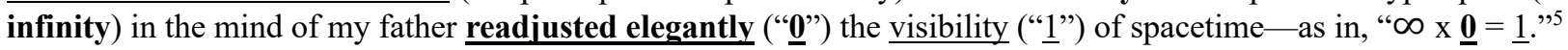

The strain of autistics to grasp figures of speech suggests that infinite-speed and nothingness in quantum computing readjust finite-speed and matter-form in classical computing through the Universal Grammar that stirs the social mind and the cosmos. Recall Peirce's examples $(1868, \S 4)$ about "There is no griffin" and "A griffin is a winged quadruped." Within coherence, a griffin invites curious readers to stand simultaneously (ubiquity) on the earth and in the sky.

We can also attribute to coherence the fact that a lion and an eagle share the same space at the same time in a griffin. Yet, only accepting as an irony the alleged inexistence of a griffin compels readers to decohere into a cosmos filled with renovated sanity and hope. The search for quantum gravity is not ironic.

Here, I use the ironic ideas of Charles Sanders Peirce, the limited interpretation of his Semiotics by Charles W. Morris (Padrón, 1996), and the logos heuristics in gaging the Universal Grammar behind humane intersubjectivity. I found that most readers read exciting texts "without reading" them. If we do not regain our individual Third Point, Common Sense, and the sociality behind the Universal Grammar that allows us to read, we will force a hellish "text" on children abandoned into a chaotic environment: "Leave behind any hope, you who enter" (Alighieri, 1555, Inferno, Canto III). ${ }^{6}$

\section{Method}

The problems studied in the Background, the explanations examined in the Discussion, and the results I offer here may create more problems. In this article about the neuropsychological roots of the Universal Grammar, I appeal to the

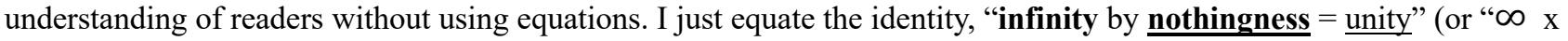
$\underline{\mathbf{0}}=\underline{1}$ ”) to the Distributed Organization of the Universal Grammar.

\footnotetext{
${ }^{5}$ Dividing 1 dollar by 100 gives 1 cent; 1 dollar divided by $10^{6}$ gives 1 millionth; and 1 dollar divided infinity gives $\underline{\mathbf{0}}$.

${ }^{6}$ My translation from ancient Tuscan dialect/Italian.
} 


\section{Results}

I conclude here that:

$\underline{1}$. The finite "being" and "speed" ("1") of arbitrary physical means, syntax rules, and prototypical meanings in any language — or the particular grammar behind our first attention/intention - resides in our cerebral cortex $([+1]$ or the Pyramid of the Sun in figure 2); and the world of chaotic "nonbeing" (the bird of lunacy/madness [-1] kicked by "Tonantzin"/"The Virgin of Guadalupe" at the center of figure 2), in denying copies stored in our cerebellar cortex;

2. pragmatics, within the coherence of quantum divergence and infinite speed ("ळ"), concurs with nonlocal long-term potentiation (LTP) ("Coatl-quetzal goes," or [2] in figure 2), the joint attention by which a one-year-old girl points to the "tree of the knowledge of good and evil" with her index finger and the second attention nonlocalized in the columns of her cerebellar microcomplexes;

$\underline{\mathbf{3}}$. finally, the Third Attention, or the Universal Grammar, starts with decoherence ("ㅁ”) in long-term

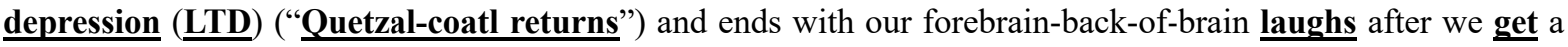
pun ( $\mathbf{3}$ in figure 2), or become aware of the divine reality of the Tree-of-Life and of any irony.

The previous results may lead to social artificial extensions, capable of translating appropriately figures of speech, ironies, and puns. Still, we will not be able to build an ironical artificial interpreter without getting the social implications of the Universal Grammar, the Tree-of-Life, or the identity " $\infty$ x $\underline{\mathbf{0}}=\underline{1}$ " behind all languages.

\section{Background}

The melting of methyl clathrates from seeps of deep gas at the bottom of some seas and the thawing of organic material in the permafrost could disturb the tipping point of the Arctic as a carbon sink. At $1000 \mathrm{ppm}$ of carbon dioxide $\left(\mathrm{CO}_{2}\right)$ in the atmosphere, the chemocline that separates sulphur-fed from oxygen-fed bacteria in our seas would start rising (Ward, 2006). If that feedback occurred, vast amounts of methane, $\mathrm{CO}_{2}$, and hydrogen sulfide $\left(\mathrm{H}_{2} \mathrm{~S}\right)$ would enter Earth's atmosphere - a fact that would intensify global warming, shock the ozone layer, and kill most species and us too early.

The sterile obedience of brainwashed cadres will prove unable to seize the challenges imposed by global warming, plunging us too into the ongoing $6^{\text {th }}$ extinction (Cassella, 2017a, 2018c, 2018e). Knowledge of the thought impaired in autism, however, can help us evade the horror that would beseech our children. Indeed, "Con-science" of the Science behind humane irony and the Universal Grammar could swap a karma of chaos for a dharma of progress.

\subsection{The One and the Many from Charles Sanders Peirce and Ferdinand de Saussure to Heraclitus}

By considering the Irony of uniting mutually exclusive relationships - as in "There is no griffin," and "A griffin is a winged quadruped" (Peirce, 1868, p. 287, § 4) -infinity and nothingness in Charles Sanders Peirce's pragmaticism (Peirce, 1905, p. 483 and p. 492) can help us reinterpret the union of Darwinian need with chance.

Peirce hoped that the scientific base of Pragmaticism would side with God's inscrutability in protecting creators from adverse events (Peirce, $1908,5^{\text {th }}$ section, $2^{\text {nd }} \S$ ). He implied the existence of infinite speed and infinite divisibility (Sfendoni-Mentzou, 2006, p. 269) in social minds, whereas the "semiology" launched by Ferdinand de Saussure never harmonized the infinity that stirs an artless talk with the finiteness behind the dull words and rules of any language.

In the early $20^{\text {th }}$ century, students' notes from the Swiss Ferdinand de Saussure agreed with the aims of "semiosis," in which any language ("langue" in French) uses arbitrary clusters of physical means ("paroles") associated to meanings ("idées") within a particular syntax. Because he studied Homer's Greek and ancient Sanskrit, de Saussure may have known about the grammar writings of the Hindu Pạnini $\left(5^{\text {th }}\right.$ century BCE) and the Greek Dionysius Thrax $\left(2^{\text {nd }}\right.$ century BCE). I assume that his limited contribution to the exploration of the Universal Grammar never went beyond the combination of the "syntagmatic" chain of words by which a horse asks the barman of a Western saloon for a double whisky; and tells its rider that he can have only a glass of milk (paradigmatic substitution), because "he has to drive."

Although Roger Bacon did not match Arthur Köestler (1964) in recognizing the paradoxical principles behind a joke, in the Middle Ages Doctor Mirabilis acknowledged that a unique philosopher's stone underlies human discourse. In fact, he wrote that, "Under the substance of any language lies one and the same grammar, although it may vary by accident" (Hovhauden, 1990, p. 123). ${ }^{7}$

Saint John's verse, "in the beginning was the Word (Logos), and the Word was with God, and the Word was God" (John 1:1, KJV) goes deeper: The uniplural nature of human languages "walks with" the nature of God.

The Greek philosopher Plato (Hamilton and Cairns, 1961) preceded Peirce, Roger Bacon, and Saint John in highlighting in the $4^{\text {th }}$ century BCE the union of rigid being with flexible being-and-nonbeing. In all dialogues by Plato, but

\footnotetext{
${ }^{7}$ My translation from Latin; and my combination of underlying with bold.
} 
Parmenides, Socrates uses his "irony" (coherence in the second attention) to discredit the knowledge of his interlocutors; and his "maieutics" (decoherence in the Third Attention), to rebuild it-without undermining the rigid Parmenidean perfection attached to unchanging ideas (the first attention).

In Plato's Parmenides, however, an old and fictional Parmenides travels from Italy to Athens to teach a young Socrates about the flexibility of less-than-perfection - in which "unity joins plurality, like joins the unlike, and "being joins nonbeing". That view, at once doubting and hopeful, would have been anathema to the real Parmenides.

One century before Plato, the real Parmenides praised the immortality of an invariant being (figure 3 , central band, $+\underline{1}$ opposed to -1 in the first attention) when he wrote, "To understand and to say must be being; being exists, nothing is not" (Cerri, 1999). ${ }^{8}$ Parmenides criticized the slightly older philosopher Heraclitus for writing, "The way up and the way down are one and the same thing" (Cappelletti, 1972). ${ }^{9}$ Actually, Parmenides wrote, "People with two heads; . . who think that being and nonbeing are and are not the same thing" (Cerri, 1999). ${ }^{10}$

Beyond the rigor of Parmenides, Heraclitus and Plato realized that we may unite ill-assorted meanings (e.g., in puns and the upper part of figure 3) - in order to win with whomever we laugh with or cry with (프).

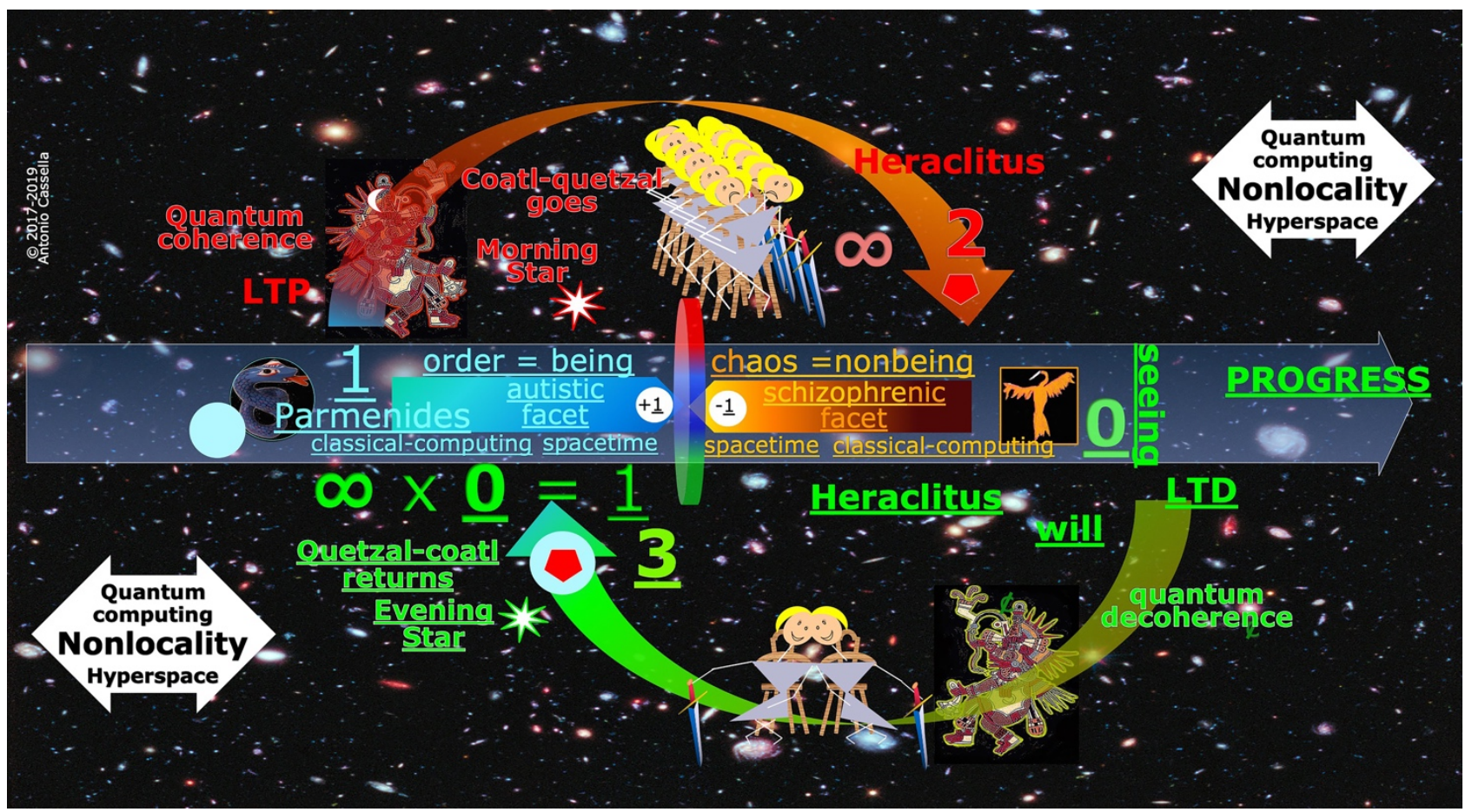

Figure 3. Parmenides' being-opposed-to-nonbeing $(+1$ and -1$)$ and the coherence-decoherence $(\mathbf{2}$ and $\underline{\mathbf{3}})$ of Heraclitus

In order to read, laugh and cry with others, or convince others, we need both the autistic facet of Parmenides and the artistic facet of Heraclitus, classical rigidity and quantum flexibility, bread and wine, perfection and less-than-perfection, literal and esoteric reading, finite and infinite speed, or rigid grammar and flexible pragmatics.

\subsection{Social Interaction and the Name of God}

A millennium before Heraclitus and Parmenides, the Pentateuch authored by Moses (Katznelson, 1991) included a dialogue between that author and God (Exodus 3:13, KJV):

“. . . The cry of the children of Israel is come unto Me: . . Come now therefore, and I will send thee unto Pharaoh, that thou mayest bring forth the children of Israel out of Egypt" . . . And Moses said unto God, "Behold, when I come unto the children of Israel, and I shall say unto them, 'The God of your fathers hath sent me unto you'; and they shall say to me, 'What is His name?' what shall I say unto them?'. . And He said, "Thus shalt thou say unto the children of Israel, 'I Am' hath sent me unto you.",

\footnotetext{
${ }^{8}$ My translation from Italian.

${ }^{9}$ My translation from Spanish.

${ }^{10}$ My translation from Italian.
} 
Since any person calls himself/herself "I Am," the name "I Am" (Cassella, 2018c) stands for the name of God and for any social interaction between the self and the other. In any intersubjective discourse, two socially-minded "I am" enrich each other by taking the place of the other-without moving from where they "are" - in a divine combination of infinite and finite speed.

God's words to Moses explain the success of the Italian 1938-song "Un'ora sola ti vorrei," written by Umberto Bertini with music by Pacia Marchetti. In the verses, "Un'ora sola ti vorrei, per dirti quello che non sai ..." ("If I had just one hour with you, I would tell you what you do not know" ${ }^{\text {"11 }}$ ), this song implies that in a short time (one hour, for example) any "I Am" might enrich the knowledge of another "I Am."

The power envisioned by God, Moses, and Bertini's/Marchetti's popular song is depicted in the "Johari window."

\subsection{The Self and the Other in the Johari Window}

In 1992, Joseph Luft explained to me in Colorado the implications of the four panes of the Johari window (figure 4) that he and Harrington Ingham had devised in the mid " $50 \mathrm{~s}$. As shown by the two left windows of figure 4, there is an "I am" pane, in which the knowledge of the self is transparent to others as well. Likewise, we all guard a pane unknown to others; a pane in which others know something of us that we do not know; and a pane unknown to the self and the other.

In any Johari window, mutual trust leads the "I am" of two interlocutors to grow (stage 3 in figure 4). That said, the philosophical, psychological, and neural path by which we jump from stage 1 to stage 3 in the Johari metaphorical window remains enigmatic.

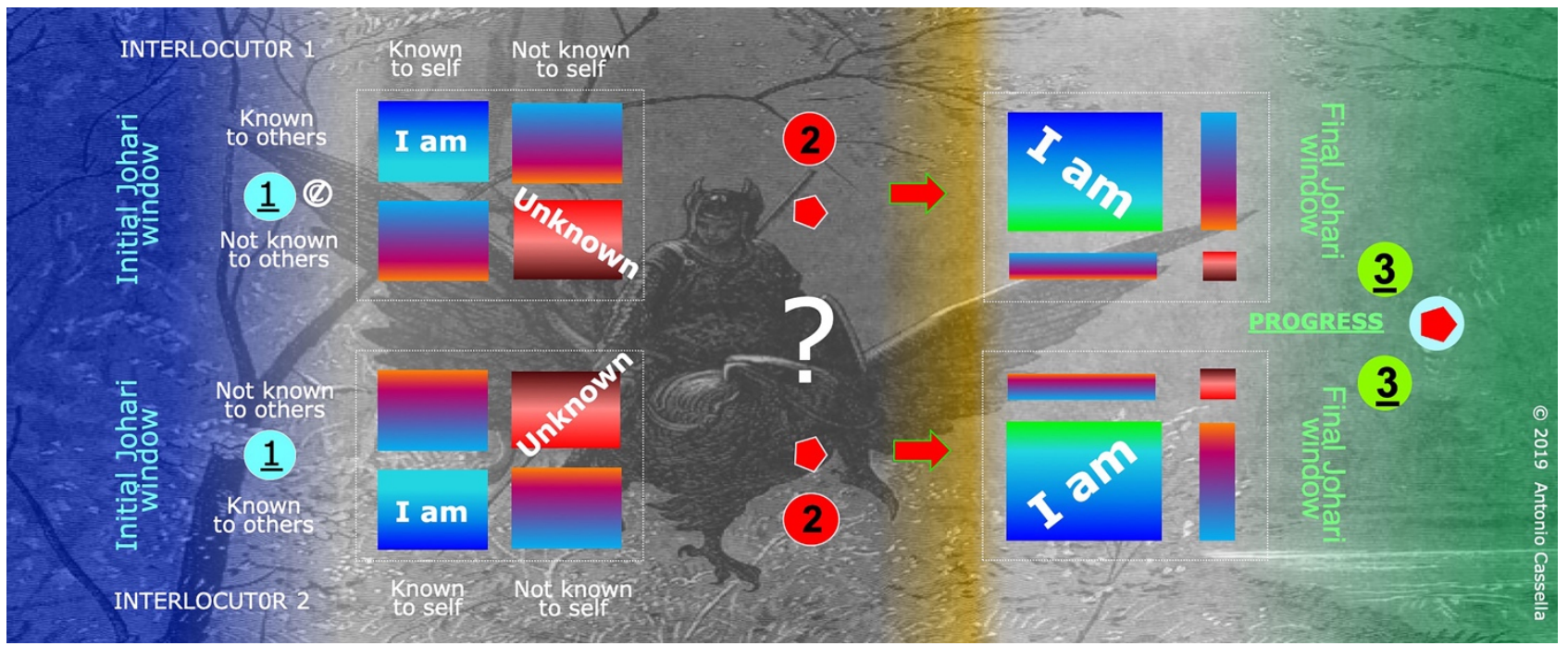

Figure 4. The self and the other in the Johari window

We may crack the enigma of the road to Progress in the Johari window by considering that most philosophies (Cooper, 1996; Ricoeur, 1991) imply Noah Chomsky's proposition (Lyons, 1978) that our minds retain the genetic effects of an unknown universal organization behind the natural intersubjectivity that enriches the self and the other.

\subsection{The Concept of a Universal Grammar in Noah Chomsky, Charles Sanders Peirce, and Charles W. Morris}

To explain Chomsky's point, consider a nonautistic preschooler who uses a vocabulary of only 90 meanings. Choosing among 90 different permutations responds to the factorial of 90, or the number 15 followed by 137 zeroes (Cassella, $2018 \mathrm{c}$ ). The fact that nonautistics may give an opinion by choosing naturally their words among a vast number of competing alternatives truly reflects a cognitive miracle. Misinterpretation, however, is always possible!

His initial choice of an ill-suited example about the practical effects of humans' creativity, for instance, places Peirce as the founder of American pragmatism, with William James and John Dewey. Still, Peirce aimed at something deeper than using hands-on schemes (e.g., saddles, plows, guns, etc.) in exploiting the world (Peirce, 1908, section V, $6^{\text {th }} \S$ ).

In time (Peirce, 1905, p. 483 and p. 492), his Third Point led Peirce to use the word "pragmaticism" to highlight the social impulse hidden in the works he wrote in the isolation of his dwelling. Peirce realized that hope and humility can lead the "implicit self" beyond Cartesian doubt. Peirce's work implies that behind Descartes" "I think, therefore I am"

11 My translation. 
(Parmenides' being) "lies" a liar who "is and is not" (the griffin in figure 4) before landing into a better self-other. That is akin to the wisdom of King Solomon, who lied in giving an infant to his true mother (1 Kings 3:16-28, KJV).

Charles W. Morris, heavily influenced by behaviorism (Deledalle, 2000, pp. 115-118), structured Peirce's pragmaticism in an incomplete semiotics, which underscored nevertheless the essentiality of two components of creative discourse (Padrón, 1996): rigid rules (grammar) and their flexible use (pragmatics).

In researching pragmaticism and semiotics in 1998-2000, I took José Padrón's offer at Caracas's UNESR (Universidad Nacional Experimental Simón Rodríguez) to add a qualitative drive to the research I had undertaken in Cambridge (MA) with Alfonso Caramazza (Harvard University) and Helen Tager-Flusberg (U-Mass then; and Boston University now). I will recap here and now the major steps of my research at Harvard and UNESR (Cassella, 1997, 2000, 2011).

\subsection{The Damage to the Alliance of the Like with the Unlike in Autism}

Within my quantitative search, in the summer of 1996, I examined a group of 18 subjects (16 autistics and two geniuses). Helen Tager-Flusberg introduced a task (False Belief) in which my subjects had to choose a false over a true belief. Doing that implies mastering quantum meta-representation, which is equivalent to choosing after seeing simultaneously the two sides of a coin or mounting a griffin. I introduced Proper Self - out of an unpublished protocol (at the moment) provided by Daniel Povinelli (Povinelli, Landau, and Perilloux, 1996). In Proper Self, my subjects had to spot the invariance of their self over time (classical meta-representation as a finite link between two known concepts, which Down subjects cannot handle).

Because they could not meta-represent, my intellectually disabled ${ }^{12}$ autistics failed False Belief and Proper Self; the genial subjects passed both tasks; and my high-functioning autistics failed False Belief as expected (Baron-Cohen, 1995). Their passing Proper Self (Cassella, 1997) ${ }^{13}$ though, demonstrates the need and insufficiency of the first attention. As any griffin shows, classical supports quantum meta-representation only in nonautistic subjects.

My qualitative research at UNESR (Cassella, 2000) led to understanding why nonretarded autistic adults trail normal four-month-olds in shifting their attention between opposite stimuli (Courchesne et al., 1994; Johnson, 1995). Later, the work of Landry and Bryson (2004) aligned with my hypothesis that autistics lack the neural capacity to tackle infinite speed in the shifts of attention attached to doubting. However, autistics' anchoring in alleged truth might result advantageous in tasks in which there is no spurious doubting. One example is "Zaitchik's Photo Task" (Zaitchik, 1990).

In the early 2000s, I realized through Perner (1991) that infinite speed forces normal subjects to trail autistics in tasks in which finite speed is the only passenger of the ship of knowledge. In Zaitchik's Photo task about the invariance of the other, autistics beat nonautistics in remembering who was lying on a mat when a picture was taken of their situation. ${ }^{14}$

Figure 5 sums up the results of my attempts (Cassella, 2000) to harmonize infinite with finite speed by crossing my qualitative search at UNESR with the quantitative search that I had performed at Harvard University. The union of the two searches told me that autistics cannot follow simultaneously their "I am" and the different "I am" of others. They cannot deal with the word "maybe," in which the "no" of nonbeing (i.e., a false belief) embraces the "yes" of being.

In essence, autistics cannot mount a griffin in leaving spacetime (1) and going (2) into hyperspace through diverging quantum coherence (upper arrow in figure 5) with the Mesoamerican demigod "Coatl-quetzal" ("snake-bird," or "being-and-nonbeing"); and unmedicated schizophrenics cannot return to a renovated shared world (the lower arrow in figure 5) with "Quetzal-coatl."

At this point, I wish to recall that Piaget (Piaget, 1983; Cassella, 2000, 2018c) found that normal children pass ...

a) the first month of life, to assimilate the perfection related to proprioception in the movements of the self;

b) the following three months, to link one sensation to proprioceptive movements;

c) the eight months before the first birthday, to hook two sensations to the self;

d) the year before the second birthday, to link the self to a representation; and

e) the five years before age 7.5 , to bond at least two signs to the self, or the wicked meta-representation. ${ }^{15}$

${ }^{12}$ Intellectual disability, a euphemism for "mental retardation," is taken here as the inability to complete Piaget's revisited five-stage scale, up to age 6.5 years.

${ }^{13}$ According to Povinelli, my application of the Proper-Self protocol to autistic subjects in 1996 fed a pioneering effort.

${ }^{14}$ The Proper-Self protocol can be examined at Researchautism.com. Down subjects will fail Proper Self and Zaitchik.

${ }^{15}$ Although Piaget set the onset of meta-representation before age 7.5 years, all normal children meta-represent before the age of 6.5 years. 
Piaget missed the "is" of quantum coherence. ${ }^{16}$ Hence, he also missed the need to defeat graciously the wants of a self destined to age and die. Gretchen, the beauty deceived by Doktor Faust after he signed with his blood a pact with the devil, becomes mad; while Faust is saved after repenting (von Goethe, 1832-2014).

Johann Wolfgang von Goethe's scheme agrees with science and mysticism, since schizophrenia does not hit old people; and sincere repentance holds the key to Paradise.

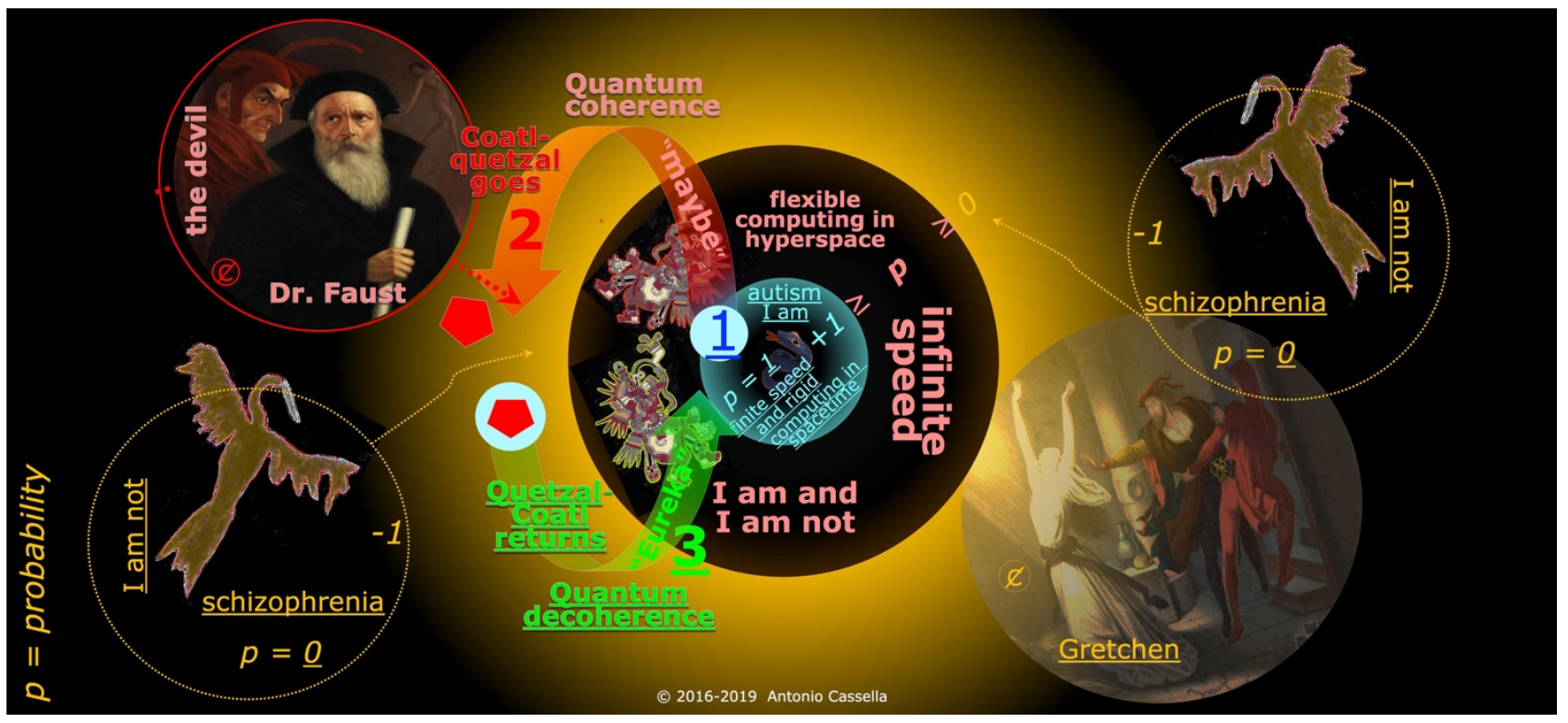

Figure 5. The classical world of "I am" (center), "I am not" (the yellow halo), and the world of "I am and I am not"

\subsection{Overcoming Temptation and Madness in Intersubjective Bouts}

Beyond the softness of von Goethe, within the logos heuristics, I follow Yu the Great, Moses, King Solomon, Laozi-Confucius, Lord Krishna, the Buddha, Christ, Quetzalcoatl, and Muhammad about the need to derail temptation in us (2). The devils that brainwash others into accepting their undeserved authority will join Gretchen in hugging their own "I am not" (the outer circle). They will never return to a better world ( $\underline{3}$ in figure 6) - unless they repent!

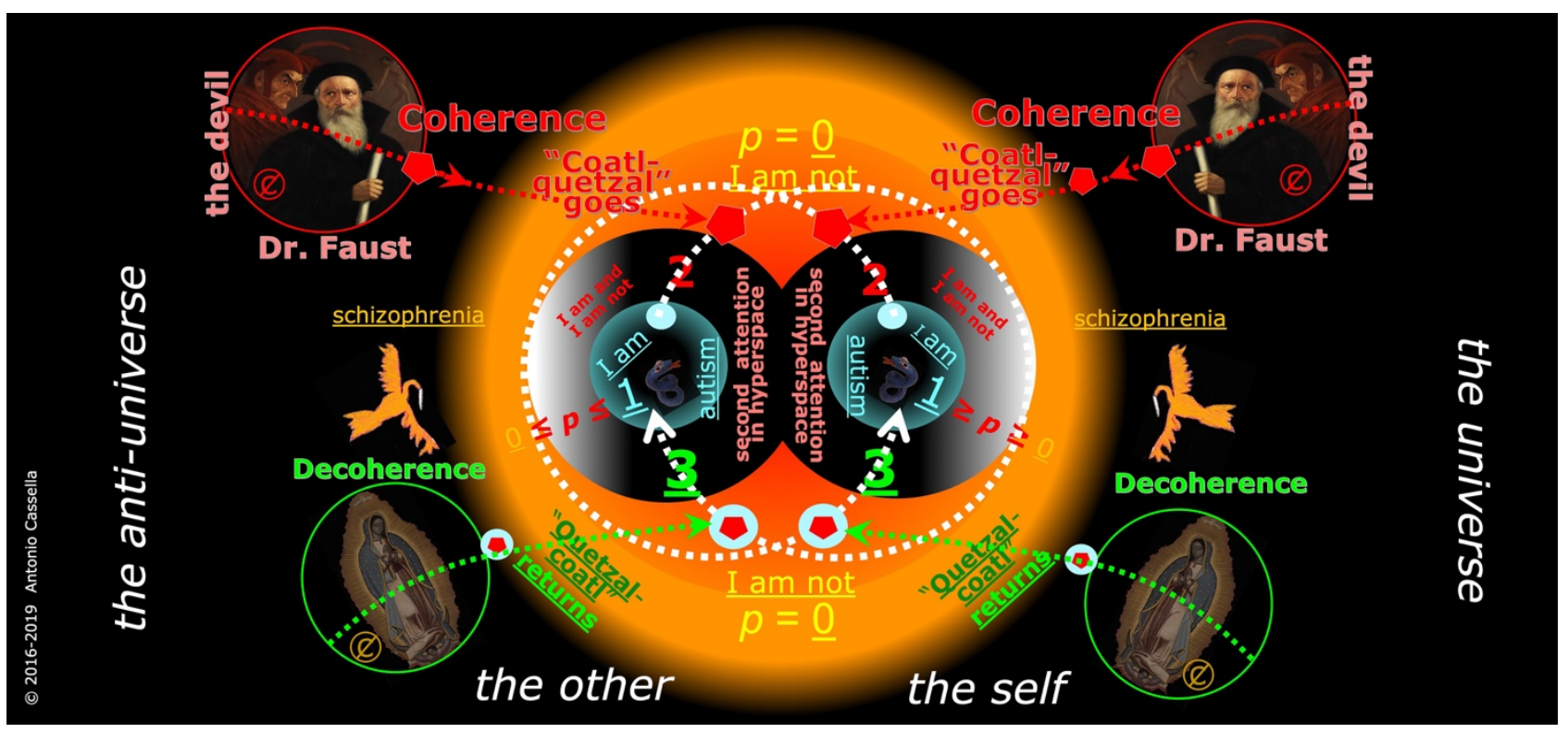

Figure 6. The meeting of the self and the other in the hyperspace of a spontaneous dialogue

${ }^{16}$ In teaching social talk to an autistic person, one has to introduce quantum computing into Piaget's classical scale. 
Mentally blind readers cannot see the cross that unites quantum coherence ( 2 in figure 7$)$, quantum decoherence (3), the principles of classical computing (left in figure 7), and the principles of quantum computing (right in figure 7).

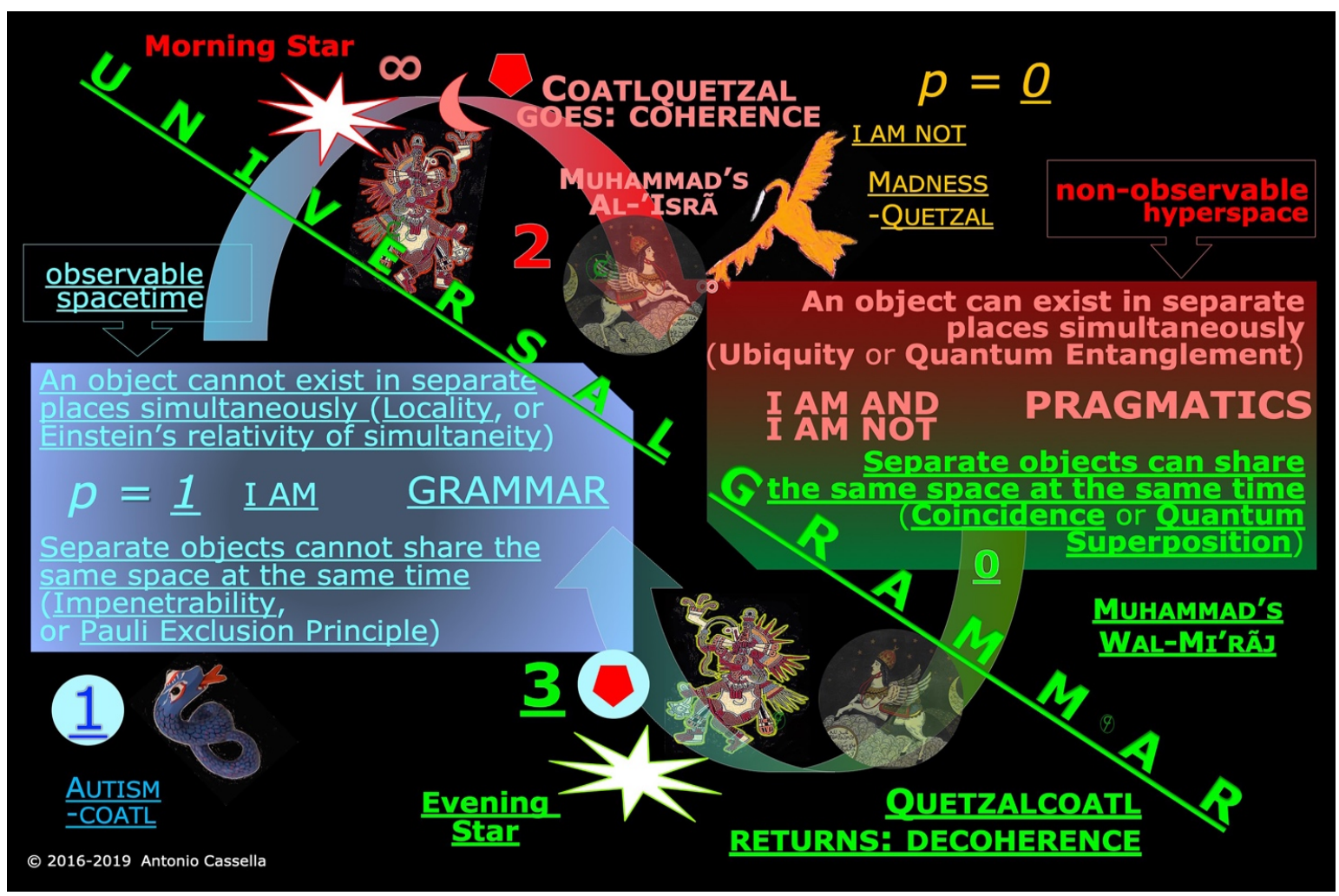

Figure 7. The principles of the logos heuristics

Dr. Deborah Zaitchik told me in 2001 that the principles impaired in autistics contradict the principles spared in them. If Muhammad's winged horse "Buraq" were considered a metaphor for the infinite speed of neural quantum computing, however, the meaning of his going (the top arrow and Al-'Isrā in figure 7) and of his returning flight (the bottom arrow and Wal-Mi'rāi), in just one night, would soar in the mind of readers whose Common Sense and Third Point wake up from the comfortable bed of truth opposed to falsity set by the finite speed of classical computing.

\section{Discussion}

The aim of the Discussion section is to arrive at the neurological implications of autistics' loss of the pragmatic capacity for entering the one-way bridge of quantum coherence (the upper arrow in figure 7 or Muhammad's Al-'Isrā) and of schizophrenics' difficulty to cross the bridge of quantum decoherence (the lower arrow or Wal-Mi'rāi).

In my aim to follow Peirce's implications about the Distributed Hierarchy of a Universal Grammar in all the languages of the cosmos, I use the principles exposed in figure 7 to join the pragmatical role of infinity $(\infty)$ and nothingness $(\underline{\mathbf{0}})$ to the sameness/repetition (1) that rules semantics-morphology, syntax, and physical means (figure 8) in any language. ${ }^{17}$

\subsection{The Role of Pragmatics in Readjusting Semantics, Syntax, and Physical Means}

Figure 8 follows Charles W. Morris's simple scheme of placing pragmatics above grammar. A Universal Grammar has to comprise the fact that, in building spontaneous dialogues and creative texts, pragmatics (the second attention/intention) readjusts grammar rules (the first attention/intention). Recall, however, that Morris's behaviorism hid from him the social dimension of Peirce's cognitive view. In the wake of most semioticians, Morris did not grasp the essence of Peirce's pragmaticism: Expose any dialogue of the self with the other to win-win situations. Morris did not realize that the devil in our second attention (figures 5 and 6) invites despots and misers to overwin.

Figure 8 follows Morris's view that physical means are readjusted by syntax; syntax, by semantics; and semantics, by pragmatics. In my interpretation of Peirce's Pragmaticism, however, without a pragmatics immersed in a social dimension, semiotics goes out, while madness comes in. As with the Aztec Tonantzin and the Hindu Aditi, true mothers

${ }^{17}$ Morris included in semantics anything that is not syntax or physical means. 
are graciously predisposed to defeat madness in following their Third Point. Relatedly, envision a mom and her deaf-mute, 10-year-old daughter.

While crying, the girl gives her parent a paper in which she has written, "a tear in my eye". A behaviorist mother would empathize with her daughter by falling into crying herself. But our mother would show a different empathy by valuing a paradoxical fact: The words "tear" associated to crying and "tear" associated to ripping are homographs.

If I had to read the previous sentence, I would read it correctly because the two homographs are clearly linked to their

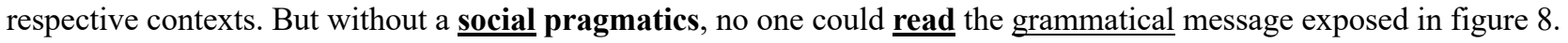

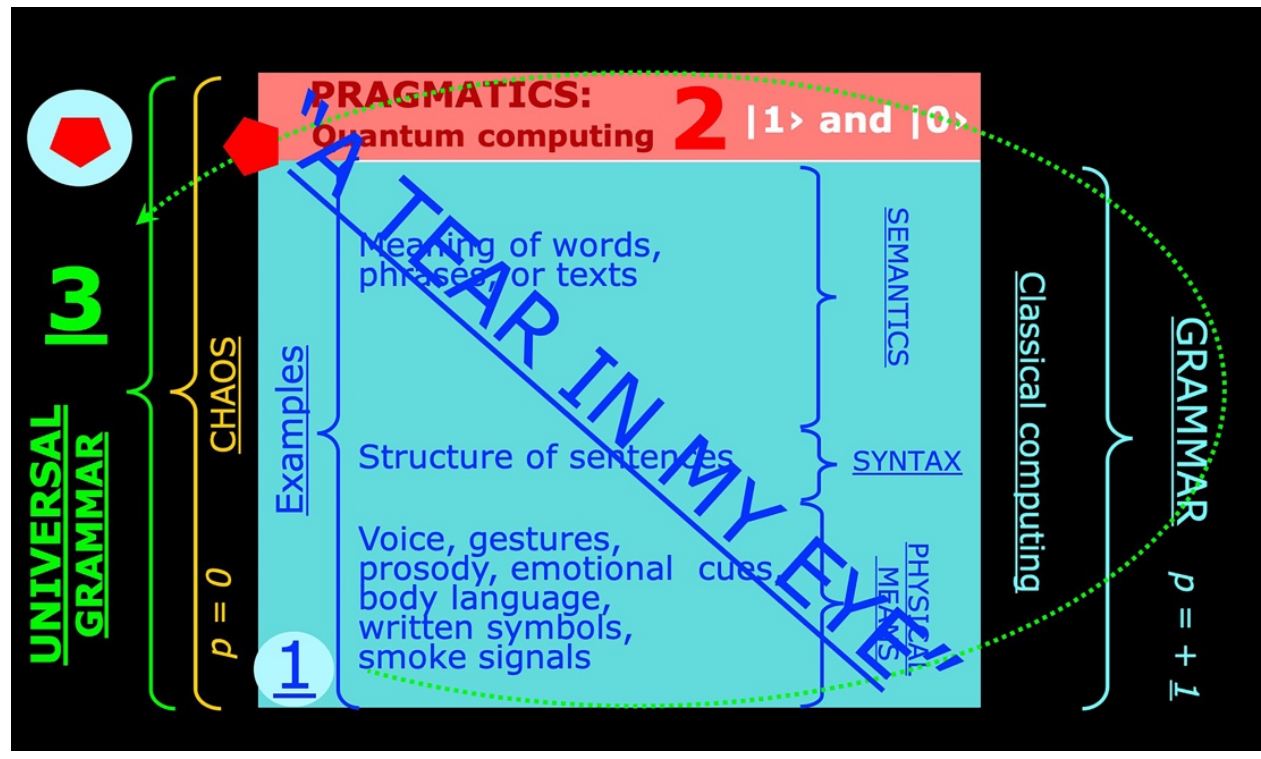

Figure 8. The Distributed Hierarchy of a Universal Grammar

Indeed, doubt about the true meaning of the message would invite any true mother to interpret the ambiguous word "tear" under the eventuality that its meaning might correspond not to a bout of sadness in her daughter but to a "tcə-ripping" in one eye and an empathic "tio-drop" in the other eye.

A true mother would "suspect" that her daughter might have had a dangerous accident; and will take her immediately to the ER (Emergency Room) in the nearest hospital. Within suspicion, any true mother would embrace the infinite speed of ubiquity by placing her self simultaneously (2) in the context of a "tear" in my dress" ("tcə," IPA) and the context of $a$ "tear" in my eye" ("tiə," IPA). After dividing her attention by embracing infinite speed, the Third Point of that mother would invite her to return to a new and hypothetical interpretation of reality ( $\underline{\mathbf{3}}$ in figure 9 ) through the principle of Coincidence (the dot/crossing-point at the right of the crossing line of the two planes).

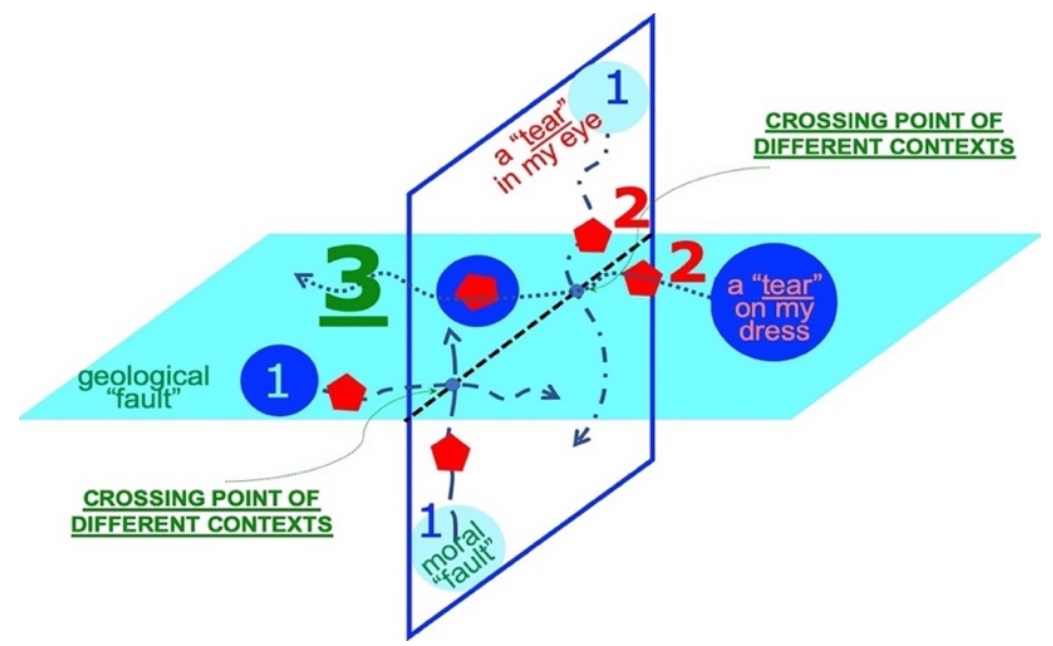

Figure 9. The crossing of contexts in homographs and puns 


\subsection{The Crossing of Different Contexts}

In facing a problem with the hope of solving it serendipitously, we cry when the problem cannot be solved; laugh and cry simultaneously when we realize that solving a problem today will lead us to an unsolvable problem tomorrow; or laugh with contentedness when we realize that unfathomable problems and amusing puns go by the same structure.

Thus, in the pun in which, after an earthquake, a small mountain tells the opposite big mountain, "It was not my fault," the witty listener will return to reality by laughing with the meaning of a geological fault and the meaning of a moral fault.

Our laugh after understanding a pun proves that the principles of Impenetrability and Locality in spacetime do not suffice to choose well or to give up choosing when we face polyvalent words (e.g., "tear" and "fault" in figure 9).

Most people do not get "missed" in the "mist" when they talk to each other or when they read a creative text because the principles of classical computing talk to the principles of quantum computing in the social mind - the reason why any decent politician can read a paper upside-down.

\subsection{The Secret of the Alphabet}

Don Juan, the "Man-of-Knowledge" who in the 1960s tried to teach the cognitive reality of quantum computing to the anthropologist Carlos Castaneda, told once his pupil about an untaught politician who was caught holding the sheet of his inaugural address upside down (Castaneda, 1974). That illiterate politician saved face by claiming that anyone could read a writing upside down - a statement that Castaneda never deepened.

At first sight, the claim of the unschooled leader seems wrong. For example, in a downside turn, the letter "b" becomes the letter "p"; and the letter "d" becomes the letter "q." To complicate matters, the letter "b" becomes the letter "d" when it is placed in front of a mirror, whereas the letter "p" becomes the letter "q" (figure 10).

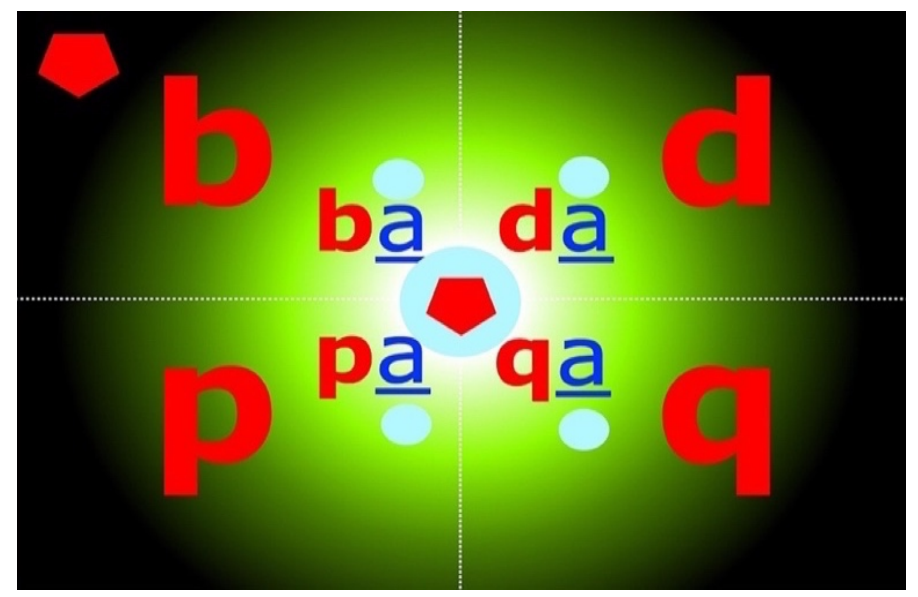

Figure 10. The secret of the English alphabet

Autistic individuals show us another facet of the mystery unleashed by polyvalent graphemes. If we show an autistic boy that the grapheme "6" should be associated with six objects, he will also associate the number "9" with six objects (Cassella, 2918c). To an autistic - more than to a nonautistic child in the process of learning how to read, the letter "b" and the letters "p," "d," and "q" make the same thing; as do the numbers "6" and "9." The reason of autistics is simple: No one can change into a different person by turning 180 degrees on a couch.

Their respect of monovalent graphemes suggests why retarded autistics will pass the "mirror self-recognition" test ascribed to age two years (Cassella, 2019b; Gallup, 1970) and will predictably fail the ToPP test related to pretend play (Clift, Stagnitti, and de Mello, 1998) at the age of two years: Autistics can fathom monovalence, not polyvalence.

Figure 10 demonstrates that the union of polyvalence (e.g., in the letter "b") with monovalence (e.g., in the letter "a") equates the union of pragmatics with grammar in the Universal Grammar behind all languages.

\subsection{The Secret of Pronouns}

In the same manner that we explore and treasure polyvalent graphemes or phonemes, we can explore and treasure any polyvalent word, be it a noun (the case of the words "fault," "tear," and "mist"), an adjective (the phoneme "missed"), a pronoun, or even a humble preposition.

By way of illustration, consider the story in which a Native American chief gives a ride to a Native American woman 
holding a bottle of whisky in her left hand. Upon looking sideways at the bottle, the driving chief says after a while, "Good whisky!" Following his words, the woman says, "I got it for my husband." "Good trade!" remarks the driver.

Suppose also that in a bank a nonautistic customer sees a pen on the floor, near the lady ahead of him in the line. He might pick it up and offer it to the potential owner with the words, "I truly know that this is not my pen; can you tell me if it is yours?" If she answers, "It is mine! How kind of you to return my pen to me here and now, just when I need it," the male customer will rest sure that he did the right thing.

Still, how could the two interlocutors understand each other if the woman called " $m y$ pen" what the man called "not my pen"? Besides using opposite determiners (my, not my) and possessive pronouns (mine, yours) in denoting the same object, they replaced their respective names with mutually exclusive personal pronouns $(I$, you $)$. The evasive qualification of "deictic" to the capacity of normal humans to adapt to context in the use of personal pronouns does not explain why autistic individuals fall into pronoun reversal (Cassella, 2018c). However, the thought that in the previous example infinite mental speed allowed both bank customers to exchange place without moving from their respective locations will do; as does the American ventriloquist Darci Lynne by existing in three places simultaneously.

Odysseus too embraced infinite speed when he told the cyclops Polyphemus that his name was "Nobody" (Pindemonte, 1922). When nearby cyclopes inquired about the pain-loaded screams of Polyphemus, whom Odysseus had blinded not to become a "hors d'œuvre," the one-eyed giant voiced harshly, "Nobody has blinded me!" His neighbors left him alone. The autistic cyclopes never saw the polyvalent mask by which a noun ("Nobody") hid behind a pronoun ("nobody").

\subsection{The Mask of Zorro}

Children are thrilled by the masked heroes (the Phantom, Batman, Spider-man, Zorro, etc.) that dwell in the "World-of-the-in-between"- or the unknown $(\mid \boldsymbol{I}>\text { and }|\boldsymbol{0}\rangle)^{18}$ between known order and unknowable chaos (figure 11).

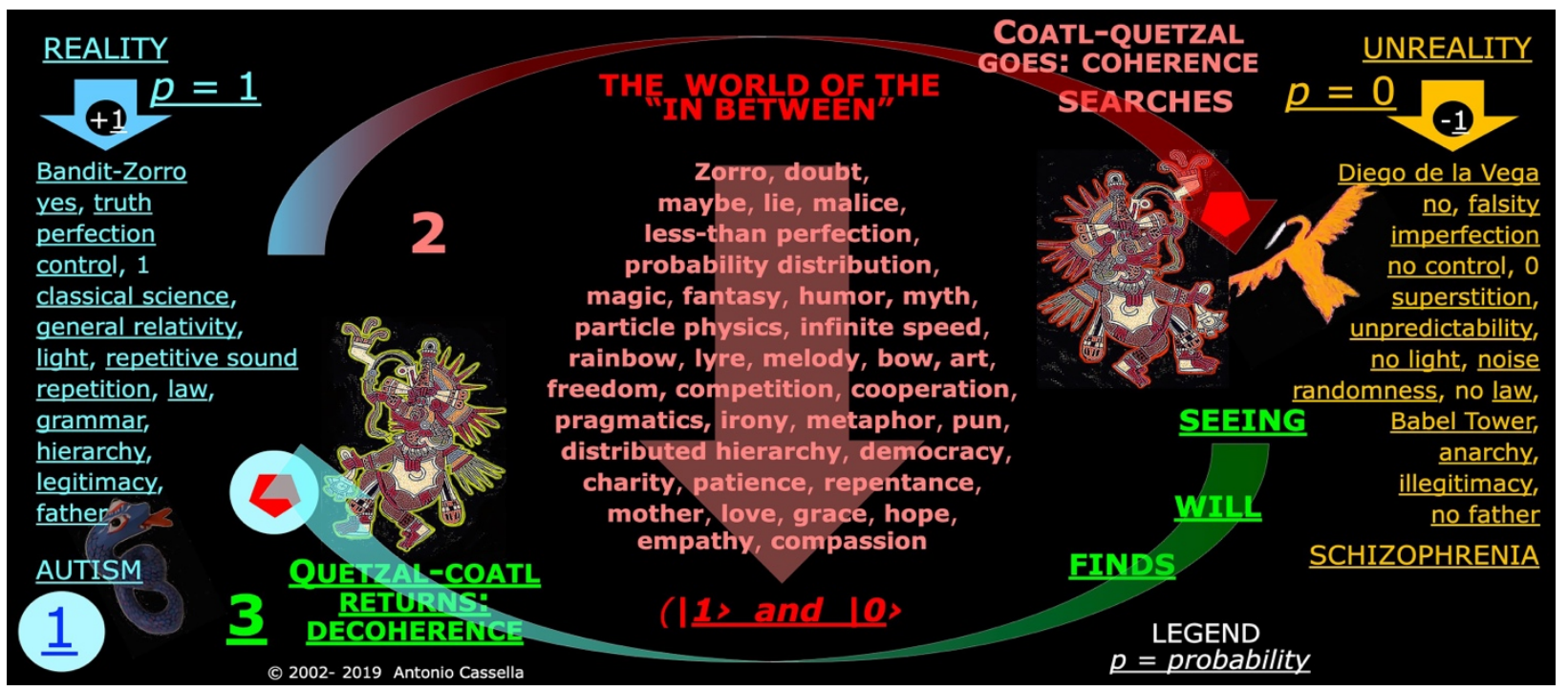

Figure 11. Zorro in the world of reality (yes, left), unreality (no, right), and the "World-of-the-In-Between"

The story goes that in the California of old lived "Diego de la Vega," a hidalgo. Under the black mask and attire of Zorro, Diego's hope and compassion (the middle column) fought a shady Governor and his Captain of the Royal Guards. ${ }^{19}$

The mysterious Zorro, his "Cordobes hat," and his rapier make the less-than-perfect world of invisible pragmatics that readjusts the perfect laws (grammar), violated by Zorro-the-bandit and respected by non-Zorro (Diego de la Vega).

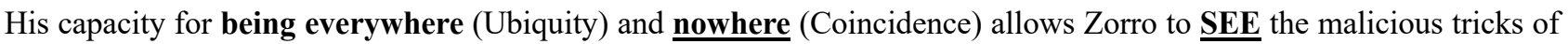
the Captain of the Guards and to WILL a better world for Californians and Mexicans alike. The main message of figure 11 is that nonbeing in the third column to the right is as important as being in the first column. If nonbeing, mosquitoes, and our enemies in the third column vanished, being and nonbeing, or the world of the "in between," would vanish too; and creativity with it.

18 Pronounced "ket one and ket zero."

19 Although Diego should go in the first column of figure 11, he has to hide in the third column to save his freedom. 
Likewise, in figure 12 the quantum power (the bow) and the infinite speed of the gray/black circles of pragmatics would vanish if either end of classical power (being or nonbeing) vanished. (I hope that despots will notice this fact before brutalizing their foes.)

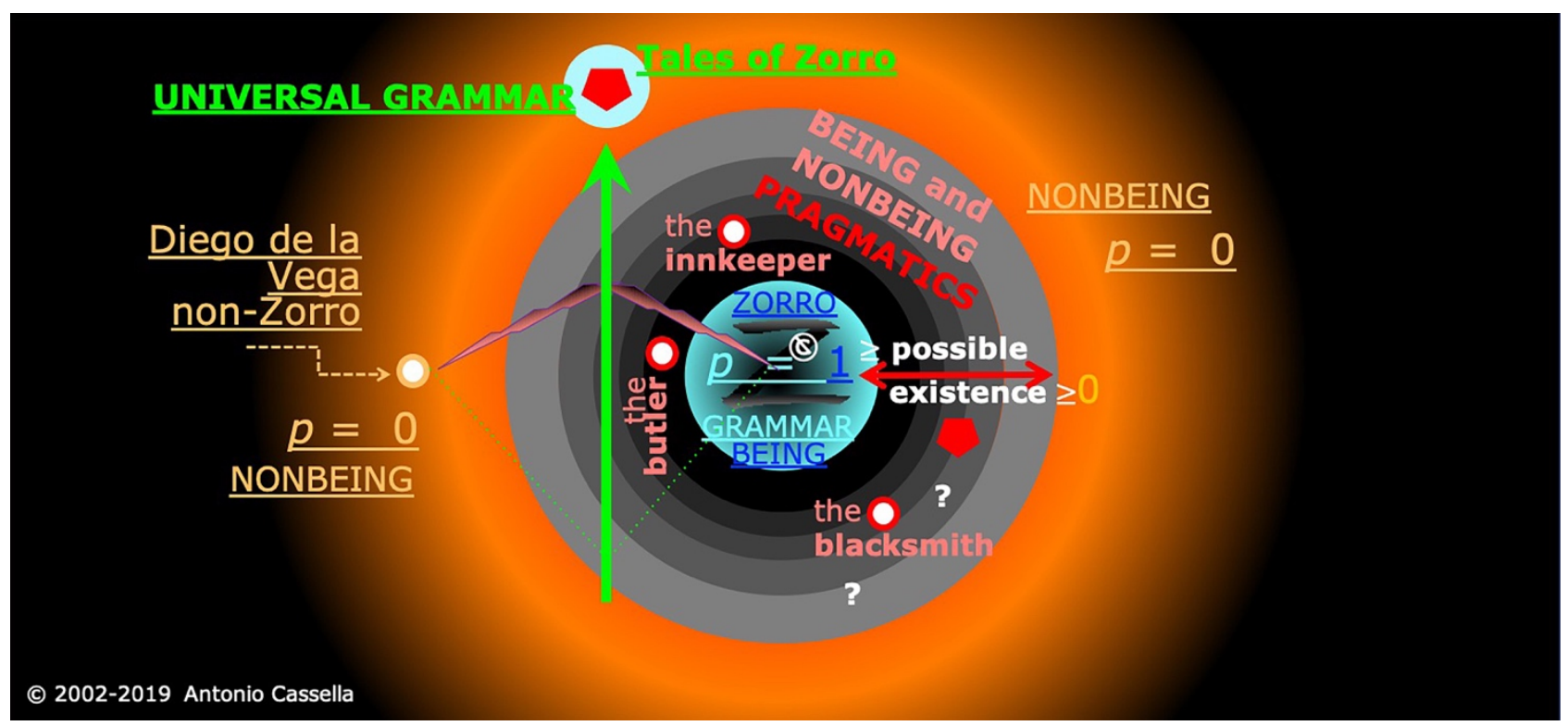

Figure 12. Zorro and his variations in the mind of the Captain of the Royal Guards

\subsection{Creating New Prototypes}

While he keeps his own routines invisible, Zorro sows doubt in the certainty of the routines followed by a few visible prototypes (e.g., his butler, the innkeeper, and the town blacksmith in figure 12). Script writers of Zorro's movies know that both Zorro (the bandit) and non-Zorro (or Diego de la Vega) must be protected in saving the tension of Zorro's fans and unknown variations, which might enter reality as new prototypes (figure 13).

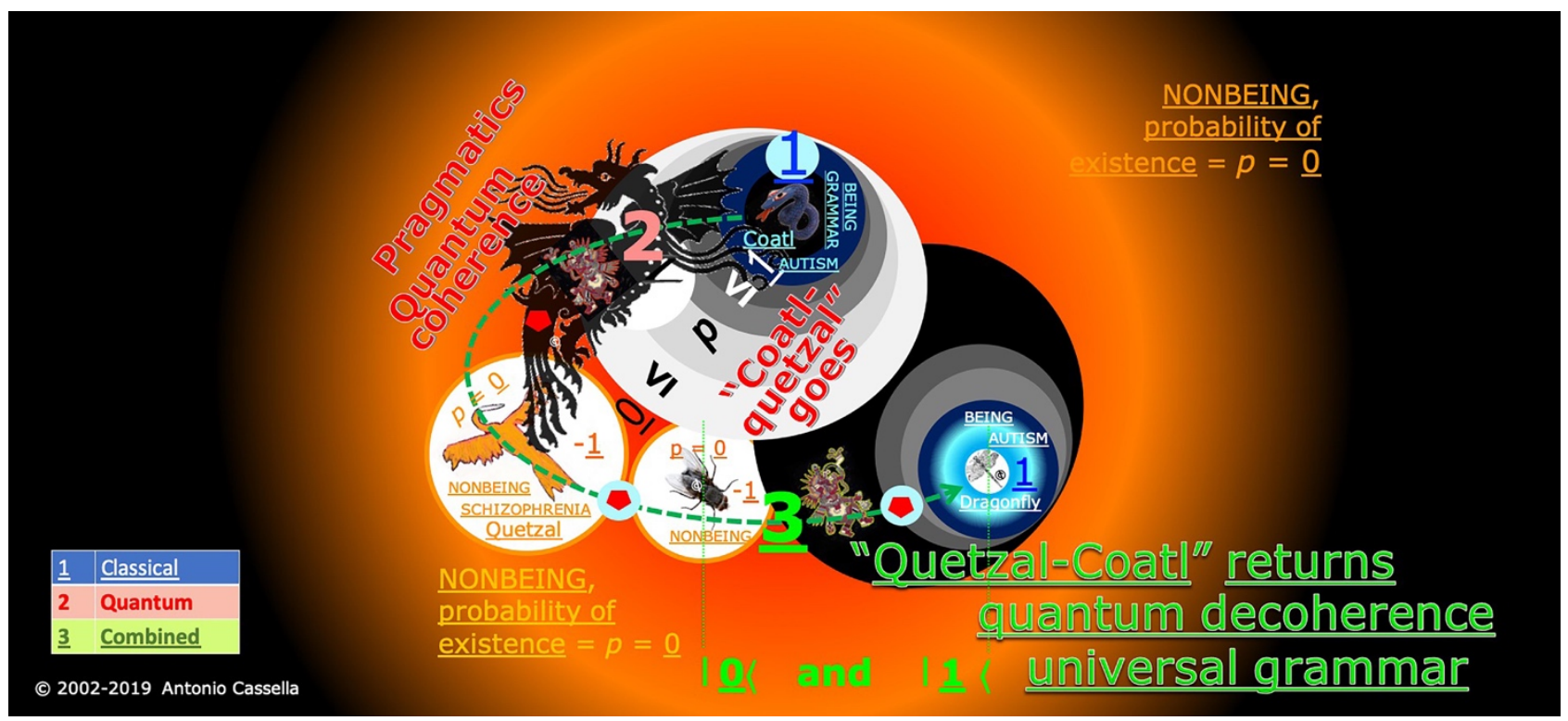

Figure 13. Being, nonbeing, and being-and-nonbeing from a snake (1), through a dragon (2), into a dragonfly ( $\underline{\mathbf{3}})$

As figure 13 shows, the tension of "Coatl-quetzal" - as a snake-scaled and bird-winged dragon-joins the prototype of a "snake" $(p=$ probability $=1)$ to the denial-nonbeing $(p=0)$ of the prototype of a "bird." Any dragon $(1 \geq p \geq 0$, Zorro, or "earth-sky") can be linked to pragmatics; and any dragon may swallow the copy of a prototypical "fly" (non-Zorro, or Diego de la Vega) in becoming a "dragonfly." 
The second attention creates new prototypes (into the Third Attention at the bottom of figure 13), after affirming and denying simultaneously the prototypes guarded by the first attention. ${ }^{20}$ I hypothesize that the being-and-nonbeing of the quantum computing inherent in simultaneous affirmation and denial cannot take place in the same autistic domain in which classical computing guards the being of prototypes (the forebrain); for prototypes are sacred.

For example, if a stroke destroyed the image of "Popeye" in our right cerebral hemisphere, we could not read the word "spinach," and perhaps the names of vegetables. Similarly, if Tarzan lost the image of the first monkey he saw, he could not separate his friend Tantor/elephant from his enemy Sabor/leopard, or read the names of the leaders (animals) that deny global warming.

Before the going of Coatl-quetzal into pragmatics (and after the return of Quetzal-coatl to the world of semantics, syntax, and physical means), prototypes can only court the classical being ruled by grammar. Thus, when Diego de la Vega talks to the Royal Captain, Zorro's butler rides in town dressed as Zorro. Equally, copies of prototypes must ride. ${ }^{21}$

Any expendable copy of a cerebral schema can be denied in the cerebellar cortex, before becoming part of the fleeting reality of being and nonbeing. Under moonlighted doubt, the masked butler accompanied by the unmasked innkeeper and blacksmith (figure 12) court pragmatics in cerebellar micro-complexes darkened by the mysterious blackness of Zorro. Mystery may hide behind a silk mask, an iron mask, and even behind an unmasked sign.

\subsection{The Man in the Iron Mask}

In Alexander Dumas' novel The man in the iron mask (Dumas, 2000), the three musketeers Porthos, Aramis, and Athos imprison in the Bastille the king of France, Louis XIV, and free his identical twin brother Philippe, who is accepted as the real king by extant courtiers in the royal palace. The trick is uncovered by Fouquet, the minister of finance, who places King Louis XIV back in power. The latter orders D'Artagnan to get rid of Philippe by sending him to the Fort Royal State Prison in Île Sainte-Marguerite, with an iron mask over his head.

In the fantasy of modern moviemaking, Philippe is avenged in 1998 by the actor Leonardo DiCaprio, who sends Louis XIV to die in prison with an iron mask over his head. The three musketeers know that behind Louis XIV's natural factions lies his identical twin brother Philippe, while "referents" (objects), "signifiers" (names), and "signifieds" (mental images) embrace the fog of the unknown in the mind of a few suspicious courtiers.

In that fog, one referent (the king of France) lies in two places at once (the royal palace and an infamous prison) and two referents (Philippe and Louis XIV) share the same space at the same time in the body of the free twin, while the use of ubiquity and coincidence feeds the tension that enlivens spectators - with an ironic twist: As with the musketeers who know the truth behind the real factions of Leonardo-DiCaprio/Louis-XIV/Philippe, we can reach the true referent behind an irony ("N," at the top of the rose-window in figure 14).

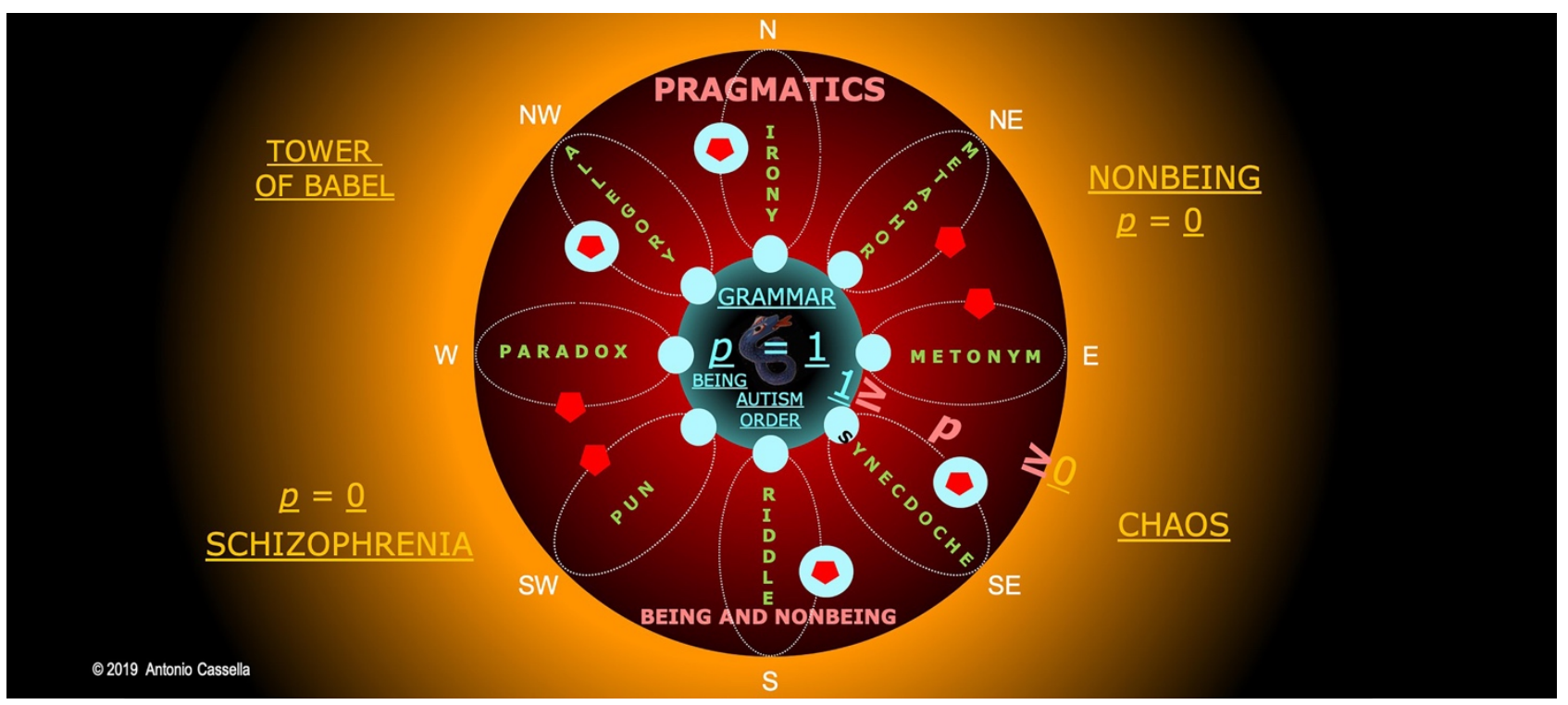

Figure 14. Polyvalence in some examples of "pragmatic" categories that autistics cannot handle

\footnotetext{
${ }^{20}$ Here, the quantum computing term $|\mathbf{1}\rangle$ and $|\mathbf{0}\rangle$ (ket one and ket 0 ) parallels the probability distribution $\underline{1} \geq \boldsymbol{p} \geq \underline{0}$.

${ }^{21}$ The author assumes that thalamic nuclei send copies of relevant information to the midbrain/hindbrain in waiting for the recognition of a problem, the finding of a new solution, or a fight or flight response.
} 
The next story might clarify the point under scrutiny. In Caracas's crime-ridden neighborhoods, most families keep closed the main door to their high-rise apartment. The teen daughter of a working mother, however, never learned that needed cautiousness.

Day after day, upon coming back from work, the worrying mother finds the door to her apartment open, until she decides to use irony in teaching her daughter about social prudence. That lucky day, the mother finds the door open, as usual. But she tells her daughter with a kind smile, "I see that today you closed the main door." Her affirmation goes against reality, for the door is open; yet her irony induces a novel shame in her girl, who stops making that maddening mistake.

Metaphor is more popular but less encompassing than irony.

5.8 The Fox of the Desert, the Riddler, Batman, and a Poor-Rich Man

Metaphor ("NE," or the second petal to the right, in figure 14) is a figure of speech ${ }^{22}$ attached to a substitution that draws on a relationship of similarity. In it, being-and-nonbeing also meddles with Ubiquity and Coincidence.

When we say that "General $\mathrm{X}$ is a fox," for instance, we do not mean that he stands simultaneously in the world of humans and in the world of animals, or that a fox and a man share the same space at the same time. We just mean that General $\mathrm{X}$ is as sly as a fox.

Metaphors are effective, gracious, and yet nonsensical. To prove the point, if General X catches a fox, the animal was not smart; and if the fox escapes General X's traps, the general cannot be smart. During World War II, General Erwin Rommel liked the nickname "Fox of the Desert," which he gained by winning several battles against the English Army in the Libyan desert. After the capture of the spy he had in Cairo, however, he had to return to Germany and Hitler-abandoning forever Africa, his metaphorical nickname, and glory.

In metonymy (figure 14, "E"), a referent is substituted for something closely associated-e.g., its cause. In the sentence that God directed to Adam, "In the sweat of thy face shalt thou eat bread ..." (Genesis, 3:19, KJV), an effect (sweating) replaces its cause (harvesting wheat) - an example of the reversible thought impaired in autism. Hence, metonymy too belongs to the pragmatics of being and nonbeing, the prohibited fruit of the "tree of the knowledge of good and evil," or the quantum coherence by which the devil tricked Eve. Metonymy is effective and real, although the callous leaders who can unleash apocalypse by releasing rockets loaded with hydrogen bombs do not sweat to make their living.

Synecdoche (figure 14, "SE") carries another trick. By replacing the part for the whole- a harm to reality that autistics will reject - a poet may paint the grief of the forsaken heroine and the elation of the fleeing hero. So did Ludovico Ariosto with the verse, "In the far distance, she saw the swollen sails of her cruel master flee" (Lipparini, 1954). ${ }^{23}$

When ironies, metonymies, or synecdoches adorn an entire artistic work, they produce an "allegory" (figure 14, "NW"), through which the whole story points at a deeper meaning, intended to shake the reader from his autistic stupor.

That is why, after leaving behind his coherence-Inferno, just before the bridge of decoherence-Purgatory, Dante writes in his Divine Comedy, "To navigate better waters, even now the vessel of my spirit lifts its sails, leaving in its wake a cruel sea" (Alighieri, 1955). ${ }^{24}$ Still, we cannot equate Dante's dream to meet "Beatrice," the lady he elevated forever, with the Riddler's dream to meet Batman, the opponent he wants to sink forever.

The pragmatic E. Nigma — or the Riddler supervillain created by Bill Finger and Dick Sprang in 1948 - corners Batman with difficult-to-solve riddles. Contrary to autistics, the masked Batman uses his midbrain/hindbrain in order to solve a riddle (figure 14, "S") in no time, to fall into the Riddler's traps in time, and to escape from them in the nick of time. The diabolical wit of the Riddler and the social wit of Batman confront each other in polyvalent hyperspace. As with Zorro, Batman always returns victorious to spacetime. (The reader may see figure 2 again.)

Different from the riddles solved by Batman, puns (figure 14, "SW") will never return to monovalent spacetime. The laugh that follows the understanding of a pun is physical, but the infinite speed sought by crossing stories in puns (figure 9), is mental only. Puns are true and false simultaneously, as in the affirmation, "This proposition is false." The previous paradox (figure 14, "W") sits down on the same chair that welcomes metaphor, metonymy, puns, and the use of the subjunctive to show off our quantum computing ability for reaching almost anywhere in hyperspace; as does the "queen" on a chessboard, the Goddess Mother, the Holy Ghost, or the Queen of the cosmos (quantum computing).

\footnotetext{
${ }^{22}$ According to Happè (1994), autistics cannot handle metaphors.

${ }^{23}$ My translation from Italian.

${ }^{24}$ My translation from Italian.
} 
In contrast with Spanish and Italian, English and Hebrew rarely use the subjunctive. However, the Jewish-American actor "Zero" Mostel used repeatedly the conjunctive "If I were" in the 1964 musical Fiddler on the roof written by Sheldon Harnick and Jerry Bock.

The verse, "If I were a rich man" of the eponymous song encompasses a play-pretend game in which Mostel (and Chaim Topol after him) imagined what it would mean to him to be rich. Because Mostel "was and was not" rich or poor while singing "If I were a rich man," he belonged to opposite worlds simultaneously (in line with the principle of Ubiquity). One may assume, then, that Mostel was conscious simultaneously — as a true actor is —of his material poverty and of his cognitive richness. Only coincidence in his midbrain/hindbrain could take him back to his forebrain -into a spacetime in which ignorance of the reality of Common Sense, the lack of Democracy, or interference in the electoral process places to-be-rich leaders into besetting cognitively $\underline{\text { rich }}$ concitizens. ${ }^{25}$

\subsection{The Relationship of the Forebrain with the Midbrain/Hindbrain}

Functional neuroimaging in persons that present selective impairment of one category of objects (e.g., "animals") over other categories (e.g., "fruits and vegetables") (Caramazza and Mahon, 2003), reasoning about the relationship of sensory modalities and object domains (Mahon and Caramazza, 2008), and a review of the theories about the organization of object knowledge in the brain (Mahon and Caramazza, 2009) suggest that the Common Sense hidden in the association of ubiquity and coincidence with locality and impenetrability, remains unrecognized.

The ignorance by which Emperor Diocletian ordered Mauritanian archers to convert Saint Sebastian into an urchin is set aside hypothetically in figure $15 .{ }^{26}$ The bow shown in figure 15 implies an archer and Peirce's Science behind irony.

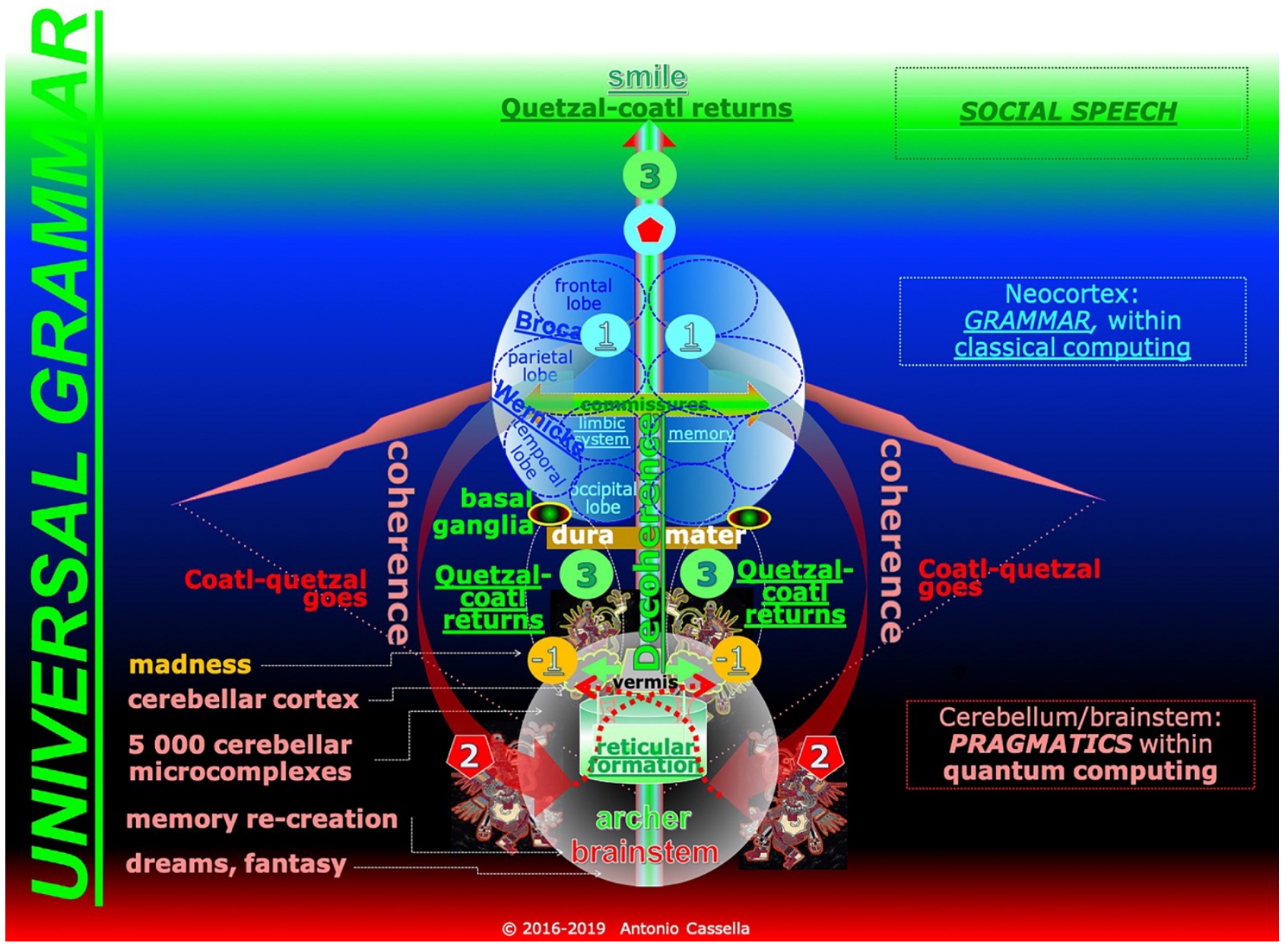

Figure 15. The "link" between grammar/classical-computing and pragmatics/quantum-computing in the brain

${ }^{25}$ At the moment, $1 \%$ cent of us are autistic; and $1 \%$, schizophrenic.

${ }^{26}$ Saint Irene cured Saint Sebastian; but the scars on his body resembled the ones of the few survivors of bubonic plague. Thus, if people without access to antibiotics were bit by fleas carrying bubonic plague, they could pray Saint Sebastian. 
Modern neuroimaging has found that syntactical rules are stored in the left cerebral hemisphere. For example, Broca's "expressive aphasia," in which a person comprehends what he or she is told but cannot speak or write, involves the frontier between the left-frontal lobe and the left-parietal lobe (Brookshire, 2007).

In Wernicke's "receptive aphasia," at the frontier between the left parietal and temporal lobes, people utter legitimate, yet empty, sentences (Kennison, 2013).

Both Broca's and Wernicke's aphasias in the forebrain point at an overseeing structure (figure 15). Also the modern philosopher, mathematician, and scientist René Descartes inferred that human intelligence transcends our forebrain. The service with Maurice Prince of Orange must have brought Descartes in the early $17^{\text {th }}$ century to see a few skulls sliced along the sagittal suture of our parietal bones by the fierce cutting edge of Hussars' curved sabers. And the sight of enemies crossed with arrows must have helped him reason out that our two different cerebral hemispheres must be coordinated by an archer removed from twin-like structures.

In place of the pineal gland chosen by Descartes, I posit that the prototypical meanings of semantics and the rules of syntax stored in the cerebral cortex are readjusted through the pragmatics hosted by cerebellar microcomplexes. Cerebellar microcomplexes guard the unique archer that helps us deal with ambiguous stimuli and discourses.

To that matter, I propose in figure 15 that an archer nonlocalized in one or more among 5000 cerebellar microcomplexes directs a cerebrum-cerebellum-brainstem-bow neurocircuitry, which coordinates both the different lobes in each cerebral hemisphere and the left hemisphere with the right hemisphere. Neuroimaging of the whole brain has shown (Buckner, 2013) that the association cortex projects to the cerebellar deep nuclei and to the contralateral cerebellar cortex.

According to Buckner, the cerebellum contains copies of the maps stored in the neocortex. The cerebrum and the cerebellum work together in mammalian species. Mammals with a large cerebrum have a large cerebellum—within a neurocircuitry built by hunting in groups an intended victim that had to escape alone. That said, the way in which the association cortex works with cerebellar microcomplexes is unknown; for one reason mainly: Lesions in the cerebellum cause subtle changes that researchers have been unable to reason out (Buckner, 2013).

The anatomy of different brains of infant and adult deceased autistics (Bauman and Kemper, 2006) and the performance of nonretarded autistics in neuropsychological tests (Cassella, 1997, 2000, 2011), however, suggest that spontaneous discourse relies on the uniplural relationship of a pragmatic nonlocality handled by cerebellar microcomplexes in the midbrain/hindbrain with a grammatical locality hosted in the forebrain.

I will discuss next the harmony of rigid-classical and flexible-quantum computing in the brain of humans and cats.

\subsection{The Crossing of Internal Models}

I described last year (Cassella, 2018b) how we may link through finite speed a purpose wanted by the self (e.g., the inverse model by which we offer a sweet to a visitor) with a purpose wanted by the other (i.e., the forward model by which a visitor extends his arm to grab the sweet). Still, a one-year-old nonautistic girl might lean on cerebellar internal models in teasing an unaware visitor by retracting her hand at the last second. Although the little girl can neither represent or meta-represent yet (recall that meta-representation arrives by age 6.5 or before), her mind can embrace simultaneously a conceding inverse model and a denying inverse model by crossing with infinite speed (Ubiquity) the chasm between being (affirmation) and nonbeing (denial). Regrettably, an adult autistic would tease no one.

As figure 16 shows from left to right, by conceding candy in the end (프), the playing youngster will return to spacetime from the Coincidence in which she had deconstructed her self. Her social concession ( $\underline{\mathbf{3}}$ in the center circle and the right circle) would follow the teasing, or musement, backed by her cerebellar Ubiquity ( 2 in the same circles).

Through teasing (2) followed by concession (3), a seven-year-old child may combine known schemata of familiar words in spontaneous and novel dialogues, in which unsettling ambiguity (2) is transformed (3) into new repetitive memories, or the togetherness of the two sides of a metaphor produces a serendipitous understanding.

In a dialogue filled with metaphors, two interlocutors go (2) into the hyperspace of neural quantum computing embedded in pragmatics by teasing each other (center-left) - before returning together (3) to the shared spacetime evoked by classical computing. That scheme suits the case of the buffalo that 40000 years ago escaped the chasing unleashed by an ambush of saber-toothed tigers or by a party of human hunters. The scheme suited also the predators.

\subsection{The Symbiosis between Saber-toothed Tigers and Buffaloes}

In a chat Masao Ito and I held in Cambridge (MA) about ten years ago, near the Picower Institute for Learning and Memory of MIT, we could not connect autism to a specific cerebellar internal model. I hypothesize now (the middle circle in figure 16) that autistics suffer an impairment in the capacity by which: a) a saber-toothed cat crossed two inverse models with two forward models to kill an escaping gazelle or b) a gazelle escaped an ambush of smart tigers. 
In other words, quantum computing in the cerebellar microcomplexes of mammals is the product of lucky ancestors, born with the capacity for adding polyvalent to monovalent computing to hunt a prey or escape a predator. Autistics cannot easily use quantum computing in re-adjusting classical computing.

We will continue to be lucky if our leaders realized that saber-toothed cats are gone, that prides of hunting lionesses are vanishing, that our pride is soaring, and that cockroaches familiar with the uselessness of WMDs, the corruption of ambitious militaries, the appetite for caviar of manufacturers of weapons, and the ills of excessive consumerism might contemplate empty squares from the heights of any wall of Washington's, Moscow's, and Tiananmen's obelisks.

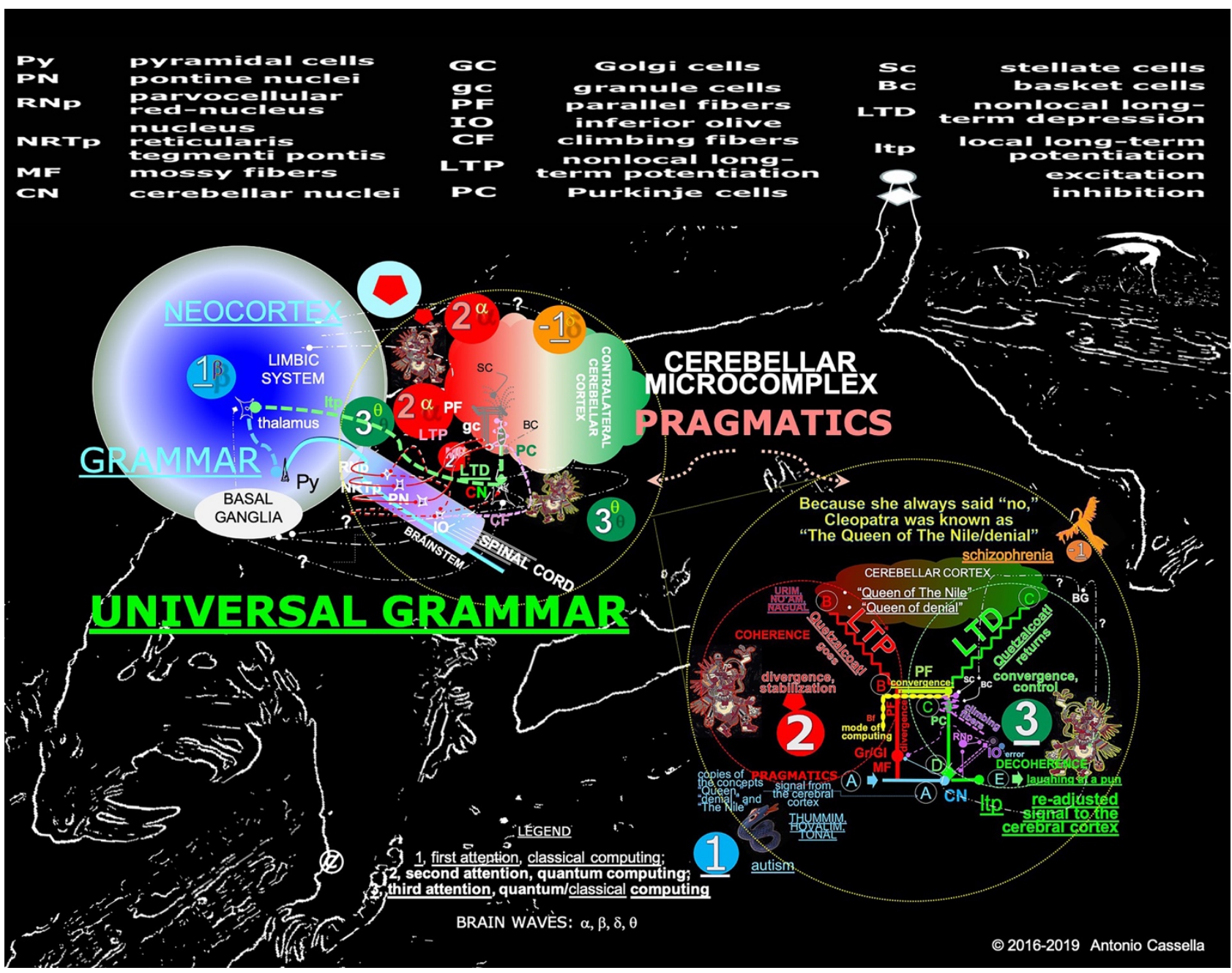

Figure 16. Searching for (2) and producing speech and puns ( $\underline{\mathbf{3}})$ between sanity (1) and madness (-1)

In line with the neural implications of Peirce's semiotics, I consider that,

- the crossing of two inverse models (in 2) precedes a speaker's ability to express a metaphor or a pun (e.g., about Cleopatra as the "Queen of The Nile/denial" at the right of figure 16) (in 3); and

- the crossing of two forward models (in 2) precedes a listener's ability to understand a pun (also in 3).

These thoughts allow hypothesizing that crossing two forward with two inverse models underlies further possibilities,

- a gazelle may escape a pride of lionesses;

- the maker and the reader of a pun may laugh together (in $\underline{\mathbf{3}}$ at the right circle in figure 16); and

○ we can regain conscience of our hard-won disposition to use common sense, to reach our Third Point, and to change our dismal future into a new opportunity of re-creation and Progress.

The latter hypothesis concurs with the dialogue that took place about 150 years ago between two Argentinian "gauchos" ("cow-boys" of the Pampas), at the south shore of the estuary of La Plata River. 


\section{Conclusion}

\subsection{A Dialogue between Two Gauchos of Old}

Figure 17 shows seven stanzas of the poem Fausto by Estanislao del Campo (1866). In Fausto, the gaucho "Anastasio el Pollo" plays with internal models stored in his cerebral memories in order to recount to a gaucho-friend of his, "Don Laguna," the gist of Gounod's Faust, which he had just seen in the "Teatro Colón" of Buenos Aires.

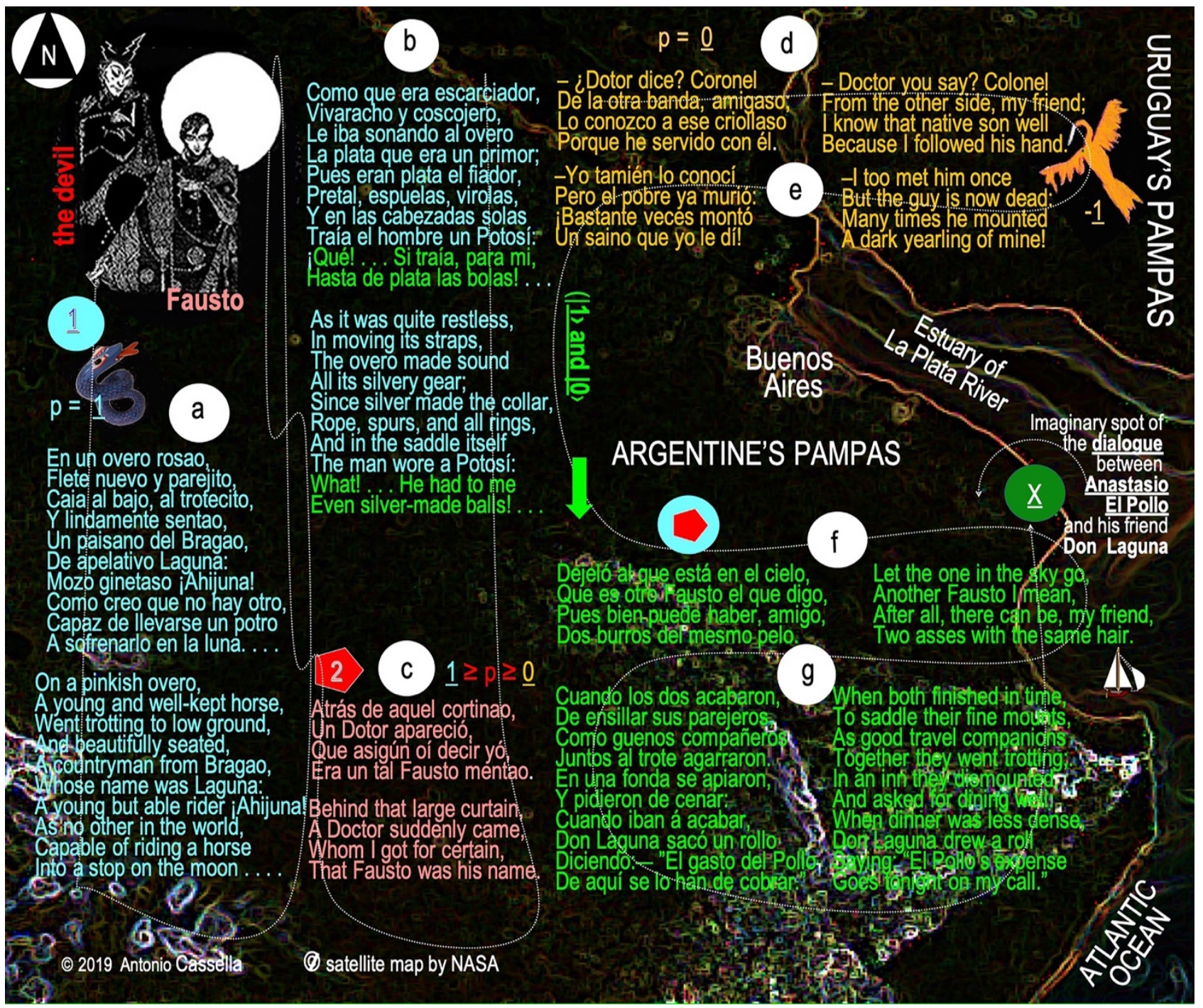

Figure 17. Seven key stanzas of Fausto, a satirical poem published in Buenos Aires by Estanislao del Campo in $1866^{27}$

Comments about the blindness to theatrical play-pretend by Don Laguna and El Pollo abound. However, the writer-poet Estanislao del Campo "knew" unconsciously that the poorest Argentinians of his time could remember (classical computing), recognize a problem (quantum coherence), and find witty solutions (quantum decoherence).

Although he makes some crazy mistakes in Fausto (stanza [d]), the role of Don Laguna cannot be limited to coherence in the second attention; whereas El Pollo clearly shows that he masters decoherence in the Third Attention. Behind the poetical discourse of both gauchos, of course, stands the cognitive richness of Estanislao del Campo, who masters the first attention (Thummim), the second attention (Urim), and the third attention (Thummim and Urim).

At the end of the second stanza (b), the sudden change that places the rider as a subject, instead of the horse, evokes the image of a gaucho with silvery balls. ${ }^{28}$

\footnotetext{
27 My translation.

${ }^{28}$ Don Laguna had won the silvery trimmings and his money in games of wit with seasoned gamblers.
} 
Quantum coherence appears with the discontent Doctor Fausto, who wants to be young again ([c] in figure 17)—a simultaneously proud and maddening proposition.

After Don Laguna's erroneous attribution of the name "Fausto" to a Uruguayan Colonel ("the other side") (d), El Pollo suggests that sometimes behind the absurdity of misinformation lies just a dismal reality (e).

In stanza (f), El Pollo implies that we may exit infinity and madness by balancing elegantly the divergence of quantum coherence with the convergence of quantum decoherence ("two asses may have the same hair").

I reason that Don Laguna took in El Pollo's kind criticism because he too was a master of the difference between classical and quantum computing. Indeed, by paying for his friend's dinner at the end of the poem (g), Don Laguna conveys his respect for the narrative ability of Anastasio El Pollo, who matched Quetzalcoatl's lynx-eyed Third Point in keeping his friend in tension until the last second of his dramatic re-interpretation of Gounod's Faust.

\subsection{Seizing Progress}

There were few mentally blind or indifferent gauchos in del Campo's time. Our pervasive indifference to the suffering of nonhuman species and the teachings of our Sacred Texts, works of art, and philosophical theories has led us into misusing the quantum power (the going "Coatl-quetzal") of the Universal Grammar and losing our discernment (the return of "Quetzal-coatl"). For instance, voters may back today corrupt despots who will lead them to pervasive poverty and massacre. Peirce wrote that "a general massacre of all who have not thought in a certain way has proved a very effective way of settling opinion in a country" (Peirce, 1877, section V, § 3). Criticizing free press precedes poverty and massacre.

Controlling alleged enemies, a country, or the entire world by intentional massacre or by the menace of chaos continues to be a sought-after strategy to remain in power. However, the devilish leaders, pseudo-scientists, and the rigid militaries who do not get the identity " $\infty$ x $\underline{\mathbf{0}}=\underline{1}$ " should examine what happened in the $6^{\text {th }}$ century CE, after a climate upheaval, to the buildings of the powerful at Teotihuacan in Central Mexico. Teotihuacans took refuge in their plan B.

In our case, taking refuge on Mars does not make a plan B. Likewise, a vast massacre will not help an emperor of the world to overcome global warming and stop the degeneration of our minds. Only Education and Gandhi's Swaraj can exchange the desire to own material goods for a cognitive wellbeing and a communitarian "disposition of heart" (Peirce, 1878 , last $\S$ of Section IV) that could help us win with the other on the road to sustainable Progress!

After seizing Peirce's pragmaticism, the power attached to the "Tree of Life" (Cassella, 2019a), memory of common sense, the return of Quetzalcoatl, and their third point, we could help our descendants by:

- having less children,

○ destroying all WMDs,

○ consuming less energy,

- using nonoffending containers, and

- restoring the Commons of the Earth (e.g., oceans, lakes, rivers, glaciers, the cycle of water, forests, the atmosphere, and the freedom of nonhuman species).

Reaching the Third Point may stop the foolish bent for changing our cool planet into hot Venus, and $\underline{\text { regain instead the }}$ $\underline{\text { Earth }}$ that hosted Smilodon saber-toothed cats 10000 years ago, when the atmosphere was cooler by $2{ }^{\circ} \mathrm{C}$.

The following five ideas may enliven our initial thrust:

a) The social relationship between pragmatics and grammar makes the Semiotics-Pragmaticism of Charles Sanders Peirce ("/p3:rs/," IPA) and the Universal Grammar behind any language in the Universe and the Anti-universe;

b) fixed rules of grammar can be linked to classical computing; and flexible pragmatics, to quantum computing;

c) grammar (first attention) is located in cerebral columns and pragmatics (second attention) is nonlocated in the columns of cerebellar microcomplexes;

d) pragmatics can be associated with cerebellar LTP (long-term potentiation) in the infinite speed of quantum coherence; and

e) our return to a renovated reality matches quantum decoherence in cerebellar LTD (long-term depression).

Although others may falsify my ideas, I cannot deny the possibility that the Wisdom of Ganesha and Kali will add my explanation about the Universal Grammar to the Dharma and Common Sense that underly a new wave of Progress.

Within Common Sense, most inhabitants of Earth will mount Peirce's griffin to sow a new wood (Giono, 2003). 


\section{Acknowledgements}

I wish to thank my wife Ligia Uribe for sustaining my dreams.

\section{About the author}

The website researchautism.com allows the downloading of free films and articles about autism and the logos heuristics.

Antonio Cassella was born in Ethiopia in 1940. He had his primary education in Italy; and high-school, in both Italy and Venezuela. In 1965 he obtained from LUZ-Maracaibo a BSc in Petroleum Engineering. For the next 17 years Antonio developed oil fields in the tidal bay of Maracaibo with Creole (a subsidiary of Esso/ExxonMobil), Lagoven, and PDVSA (Petróleos de Venezuela).

In 1976, he worked with EPRCO (Exxon Production Research) in Houston; and with Strategic Planning of PDVSA between 1983 and 1993. From 1994 to 1997 he was a scientist at MIT-CEEPR (Center for Energy and Environmental Policy Research), in Cambridge (MA). His research at MIT led to establishing two scenarios of the global growth of population, energy, and the economy; i.e., until 2060 (Cassella, 2008).

In June 1997, his exploration of autism led to a master's degree in Psychology, the Dean's List, the Thomas Small Prize, and the Award for Outstanding ALM Thesis in the Area of Natural and Human Sciences from Harvard University. In 2001 Antonio Cassella received from Universidad Nacional Experimental Simón Rodríguez (UNESR) in Caracas a doctoral degree of Research and Teaching in Sciences of Education.

His writings in Italian, Spanish, and English at Amazon and researchautism.com show that we have a limited time window to restore the Commons of the Earth - among them, the atmosphere, the forests, and the cycle of water.

Persons, enterprises, and institutions that want to explore a problem of their own choosing may e-mail Antonio Cassella at researchautism.1@gmail.com or press the tab CONTACT US at the website researchautism.com.

\section{References}

Alighieri, D. (1555). La Divina Comedia. Vinegia (Venice): Gabriel Giolito de Ferrari, et Fratelli.

Baron-Cohen, S. (1995). Mindblindness. Cambridge, MA: MIT Press. https://doi.org/10.7551/mitpress/4635.001.0001

Bauman, M. L., \& Kemper, T. L. (2006). “Structural brain anatomy in autism: What is the evidence?” In The neurobiology of autism, edited by Margaret Bauman and Thomas Kemper, 121-135. Baltimore: Johns Hopkins UP.

Brookshire, R. (2007). Introduction to neurogenic communication disorders. St. Louis (MO): Mosby.

Buckner, R. L. (2013). The cerebellum and cognitive function: 25 years of insight from Anatomy and neuroimaging. Neuron, 80, 807-815. http://dx.doi.org/10.1016/j.neuron.2013.10.044

del Campo, E. (1866). Fausto: Impresiones del gaucho Anastasio el Pollo en la representación de esta obra. Buenos Aires: Imprenta Buenos Aires.

Cappelletti, A. G. (1972). Los fragmentos de Heráclito. Caracas: Tiempo Nuevo.

Caramazza, A. (1994). Parallels and divergences in the acquisition and dissolution of language. Philosophical Transactions of the Royal Society of London, Series B346, 121-127. https://doi.org/10.1098/rstb.1994.0136

Caramazza, A., \& Mahon, B. Z. (2003). The organization of conceptual Knowledge: The evidence from category-specific semantic deficits. Trends of Cognitive Science, 7(8), 354-361. https://doi.org/10.1016/S1364-6613(03)00159-1

Cassella, A. (1997). Self-other differentiation and self-other integration from the perspectives of language development and autism. Unpublished master's thesis. Harvard University, USA. https://researchautism.com/books

Cassella, A. (2000). Fundamentos cognitivos y semióticos de la creatividad: Aportes del autismo. (Tesis doctoral con mención publicación). Universidad Nacional Experimental Simón Rodríguez (UNESR), Caracas, Venezuela. https://researchautism.com/books

Cassella, A. (2011, June). Autism and the interplay of deterministic and quantum information processing in the act of creation. Neuroquantology, 9(02), 271-287. https://doi.org/10.14704/nq.2011.9.2.324

Cassella, A. (2017a). Re-directing climate change and terrorism by allying classical with quantum neural computing. International Journal of Social Science Studies, 5(6), 94-115. https://doi.org/10.11114/ijsss.v5i6.2439

Cassella, A. (2017b) Freeing Leonardo da Vinci's Fight-for-the-Standard in the Hall of the Five Hundred at Florence's Palazzo Vecchio. International Journal of Social Science Studies, 5(10), 01-16. https://doi.org/10.11114/ijsss.v5i10.2657

Cassella, A. (2018a). A psychological view of complex numbers through classical and quantum computing. 
International Journal of Social Science Studies, 6(1), 66-81. https://doi.org/10.11114/ijsss.v6i1.2872

Cassella, A. (2018b). Exploring the social link between cerebral and cerebellar neural ensembles through a falsifiable psychological heuristic. International Journal of Social Science Studies, 6(2), 69-93. https://doi.org/10.11114/ijsss.v6i2.2934

Cassella, A. (2018c). Series, Thus returned Quetzalcoatl: Labyrinth 1 (The way of hunting), Labyrinth 2 (The way of war), and Labyrinth 3 (The way to progress). Melbourne (FL): Research Autism ( $4^{\text {th }}$ edition at Amazon Prime and Kindle). Retrieved from https://researchautism.com/books

Cassella, A. (2018d). Exploring the Sphinx and the Great Pyramid through the logos heuristics. International Journal of Social Science Studies, 6(9), 11-30. https://doi.org/10.11114/ijsss.v6i9.3559

Cassella, A. (2018e). Re-directing climate change and terrorism by allying classical computing and quantum computing. Melbourne (FL): Research Autism ( $4^{\text {th }}$ edition at Amazon Prime and Kindle). https://researchautism.com/books

Cassella, A. (2019a). The meaning of the Ark of the Covenant though the logos heuristics. International Journal of Social Science Studies, 7(2), 53-70. https://doi.org/10.11114/ijsss.v7i2.4080

Cassella, A. (2019b). Joining General Relativity to Particle Physics through Complex Numbers and Autism. International Journal of Social Science Studies, 7(4) (July, 2019b), 33-56. https://doi.org/10.11114/ijsss.v7i4.4338

Cerri, G. (1999). Parmenide di Elea: Poema sulla Natura. Milano: Rizzoli.

Castaneda, C. (1974). Tales of Power. New York: Simon and Schuster.

Clift, S., Stagnitti, K., \& DeMello, L. (1998). A validational study of the test of pretend play using correlational and classificational analyses. Child Language Teaching and Therapy, 14(2), 199-209. https://doi.org/10.1177/026565909801400205

Cooke, E. F. (2018). Peirce on musement. European Journal of Pragmatism and American philosophy. X2. https://doi.org/10.4000/ejpap.1370

Cooper, D. (1996). World Philosophies: An historical introduction. Cambridge (MA): Blackwell.

Courchesne, E., Townsend, J. P., Akshomoof, N. A., Yeung-Courchesne, R., Press, J. A., Murakami, J. W., ... Schreibman, L. (1994) "A new finding: Impairment in shifting attention in autistic and cerebellar patients." In Atypical cognitive deficits in developmental disorders: Implications for brain function, edited by Sarah Broman and Jordan Grafman, 101-137. Hillsdale, N.J: Erlbaum.

Deledalle, G. (2000). Charles Peirce's philosophy of signs. Bloomington (IN): Indiana University Press.

Dumas, A. (2000, Historical reprint) The man in the iron mask. USA: Trident Press International.

Feynman, R. P. (1985). QED: The strange theory of light and matter. Princeton, N.J.: Princeton University Press.

Gallup, G. G. Jr. (1970). “Chimpanzees: Self-recognition.” Science, 167, 86-87.

https://doi.org/10.1126/science.167.3914.86

Giono, J. (2003). L'uomo che piantava gli alberi. (Traduzione di Luigi Spagnol). Torino (IT): Edizioni Angolo Manzoni.

von Goethe, J. W. (1832-2014). Faust, a tragedy: Parts one and two, fully revised (translated by Martin Greenberg). London: Yale University Press.

Hamilton, E., \& Cairns, H. (1961). The collected dialogues of Plato. Princeton: Princeton University Press. https://doi.org/10.2307/j.ctt1c84fb0

Happé, F. G. E. (1994). An advanced test of theory of mind: Understanding of story characters' thoughts and feelings by able autistic, mentally handicapped and normal children and adults. Journal of Autism and Developmental Disorders, 24, 129-154. https://doi.org/10.1007/BF02172093

Hawkins, A. S., \& Cui, Y. (October 2017). A theory of how columns in the neocortex enable learning the structure of the world. Frontiers in Neural Circuits, 11, 81. https://doi.org/10.3389/fncir.2017.00081

Hovdhauden, E. (1990). Una et eadem: Some observations on Roger Bacon's Greek Grammar. In G. L. Bursill-Hall, S. Ebbesen, \& E. F. K. Korner (Eds.) De Ortu Grammaticae: Studies in medieval grammar and linguistic theory in memory of Jan Pinborg (pp. 123-126). Amsterdam: John Benjamins Publishing Company

Icke, V. (1995). The force of symmetry. Cambridge: Cambridge University Press. https://doi.org/10.1017/CBO9780511622694

Ito, M. (2011). The cerebellum: Brain for an implicit self. Upper Saddle River, NJ: Pearson Ed. 
Johnson, M. (1995). The development of visual attention: A cognitive neuroscience perspective. In M. S. Cazzaniga (Ed.), The cognitive neurosciences (pp. 735-747). Cambridge, MA: MIT Press.

Katznelson, M. (1991). La Biblia: hebreo-español. Tel Aviv: Sinai.

Kennison, S. (2013). Introduction to language development. Los Angeles: Sage.

Köestler, A. (1964). The act of creation. Hutchinson: London.

Landry, R., \& Bryson S. (2004). Impaired disengagement of attention in young children with autism. Journal of Child Psychology and Psychiatry, 45, 1115-1122. https://doi.org/10.1111/j.1469-7610.2004.00304.x

Lipparini, G. (1954). Lo stile italiano. Milano: Signorelli.

Lloyd, S. (2006). Programming the Universe. New York: Alfred E. Knopf.

Lyons, J. (1978). Noam Chomsky (revised ed.). Harmondsworth: Penguin. ISBN 978-014-0043709

Mahon, B. Z., and Caramazza, A. (2008). A critical look at the embodied cognition hypothesis and a new proposal for grounding conceptual content. Journal of Physiology Paris, 102(1-3), 59-70. https://doi.org/10.1016/j.jphysparis.2008.03.004

Mahon, B. Z., \& Caramazza, A. (2009). Concepts and categories: A cognitive Neuropsychological perspective. Annual Review of Physiology, 60, 27-51. https://doi.org/10.1146/annurev.psych.60.110707.163532

Padrón G. J. (1996). Análisis del discurso e investigación social. Caracas: UNESR.

Peirce, C. S. (1868). On a new list of categories. Proceedings of the American Academy of Arts and Sciences, 7, 287-298. https://doi.org/10.2307/20179567

Peirce, C. S. (1877). The fixation of belief. Popular Science Monthly, 12, 1-15.

Peirce, C. S. (March 1878). The doctrine of chances. Popular Science Monthly, 12.

Peirce, C. S. (October 1905). Issues of pragmaticism. The Monist, 15(4), 481-499. https://oi.org/10.5840/monist19051544

Peirce, C. S. (1908). A neglected argument for the reality of God. Hibbert Journal, 7(1), 90-112.

Perner, J. (1991). Understanding the representational mind. Cambridge (MA): MIT Press.

Piaget, J. (1983). La psicología de la inteligencia. Barcelona: Grijalbo.

Pindemonte, I. (1822). Odissea di Omero (Antichità). Verona: Società Tipografica Editrice.

Povinelli, D. J., Landau, K. R., \& Perilloux, H. K. (1996). Self-recognition in young children using delayed versus live feedback: Evidence of a developmental asynchrony. Child Development, 67, 1540-1554.

https://doi.org/10.2307/1131717

Ricoeur, P. (1991). From text to action: Essays in Hermeneutics II. Evanston: Northwestern University.

Rodríguez-Vidal, J., d’Errico F., Giles Pacheco, F., Blasco, R., Rosell, J., Jennings, R. P., ... Finlayson, C. (September 2014). A rock engraving made by Neanderthals in Gibraltar. Proceedings of the National Academy of Sciences of the United States of America, 111(37), 13301-13306. https://doi.org/10.1073/pnas.1411529111

Sfendoni-Mentzou, D. (July-Dec. 2008). C. S. Peirce and Aristotle on time. Cognitio (S. Paulo), 2(2), 261-280.

Ward, P. D. (2006). Impact from the Deep. Scientific American, 295, 64-71. https://doi.org/10.1038/scientificamerican1006-64

Zaitchik, D. (1990). When representations conflict with reality: The preschooler's problem with false beliefs and 'false' photographs. Cognition, 35, 41-68. https://doi.org/10.1016/0010-0277(90)90036-J

\section{Copyrights}

Copyright for this article is retained by the author(s), with first publication rights granted to the journal.

This is an open-access article distributed under the terms and conditions of the Creative Commons Attribution license which permits unrestricted use, distribution, and reproduction in any medium, provided the original work is properly cited. 